\title{
A near-infrared fluorescent probe for observing thionitrous acid-mediated hydrogen polysulfides formation and fluctuation in cells and in vivo under hypoxia stress
}

\author{
Xia Zhang ${ }^{\mathrm{a}, \mathrm{d}}$, Liangwei Zhang ${ }^{\mathrm{a}, \mathrm{c}}$, Min Gao ${ }^{\mathrm{a}, \mathrm{d}}$, Yunqing Wang ${ }^{\mathrm{a}, \mathrm{c}}$, Lingxin Chen ${ }^{\mathrm{a}, \mathrm{b}, \mathrm{c}, *}$ \\ ${ }^{a}$ CAS Key Laboratory of Coastal Environmental Processes and Ecological Remediation, Shandong Key Laboratory of Coastal Environmental Processes, Research Centre for \\ Coastal Environmental Engineering and Technology, Yantai Institute of Coastal Zone Research, Chinese Academy of Sciences, Yantai 264003, China \\ ${ }^{\mathrm{b}}$ Laboratory for Marine Biology and Biotechnology, Pilot National Laboratory for Marine Science and Technology, Qingdao 266237, China \\ ${ }^{\mathrm{c}}$ Center for Ocean Mega-Science, Chinese Academy of Sciences, Qingdao 266071, China \\ ${ }^{\mathrm{d}}$ University of Chinese Academy of Sciences, Beijing 100049, China
}

\section{A R T I C L E I N F O}

\section{Editor: R. Teresa}

Keywords:

Fluorescent probe

Hydrogen polysulfides

HSNO-mediated

Near-infrared imaging

Hypoxia stress

\begin{abstract}
A B S T R A C T
Hydrogen polysulfides $\left(\mathrm{H}_{2} \mathrm{~S}_{\mathrm{n}}, \mathrm{n}>1\right)$ as important intracellular reactive sulfur species (RSS) are believe to be responsible for cellular redox regulation. Lots of researches about $\mathrm{H}_{2} \mathrm{~S}_{\mathrm{n}}$ focusing on their formation, detection and bio-function in signalling regulation are spring up but with poor understanding, especially for biosynthesis and bio-function remain complicated and confusing. Recent studies reveal that thionitrous acid (HSNO) as potential intermediate linked signalling molecules of nitrogenous and sulphureous during biotic redox regulation. However, there are limited evidences for supporting the interrelation and bioeffect between HSNO and $\mathrm{H}_{2} \mathrm{~S}_{\mathrm{n}}$. Herein, we have successfully designed a near-infrared (NIR) fluorescent probe ((2-fluoro-5-nitrobenzoyl) oxy)-Benzo[e]cyanine (BCy-FN) for detection $\mathrm{H}_{2} \mathrm{~S}_{n}$ and for the first time observing HSNO-mediated $\mathrm{H}_{2} \mathrm{~S}_{\mathrm{n}}$ generation in cells and in vivo. The probe is harvested from fluorophore BCy-Keto and 2-fluoro-5-nitrobenzoic acid in one step, featuring mitochondria localization. The unique Enol-Keto tautomerization of fluorophore enables the probe becomes more sensitive and has powerful application. Hypoxia model has been constructed and powerfully interpreted the pretreatment of HSNO for zebrafish hypoxia process effectively improves $\mathrm{H}_{2} \mathrm{~S}_{n}$ levels and defends the hypoxia induced brain damage. We believe the present studies will help environmentalist and biologist for better understanding of biosynthesis and bio-function in HSNO-mediated $\mathrm{H}_{2} \mathrm{~S}_{\mathrm{n}}$ formation process under hypoxia stress.
\end{abstract}

\section{Introduction}

Hypoxia is now a global and pressing environmental problem, which results in deleterious ecological effects; therefore, it has received scientific attention increasingly. Homeostasis of oxygen is critical for organism redox homeostasis, it will lead to a cascade of detrimental cellular responses and initiate tissue damage, result in organ failure ultimately if this homeostasis disrupted. Reactive sulfur species (RSS) are a family of sulfur-containing reductive biomolecules, including biothiols, hydrogen sulfide $\left(\mathrm{H}_{2} \mathrm{~S}\right)$, hydrogen polysulfides $\left(\mathrm{H}_{2} \mathrm{~S}_{\mathrm{n}}, \mathrm{n}>1\right)$, sulfane sulfur (RSSH, RSSnSR), S-modified protein cysteine adducts (Snitrosothiols, RSNO), and so on (Filipovic et al., 2017; Paulsen and Carroll, 2013; Kang et al., 2018). Having been suggested as actual bioactive molecules for " $\mathrm{H}_{2} \mathrm{~S}$ signalling" in cells, $\mathrm{H}_{2} \mathrm{~S}_{\mathrm{n}}$ are believe to involve in signal regulatory process in biological systems similar to other two prestigious signalling gasotransmitter, nitric oxide (NO) and carbon monoxide (CO) (Ono et al., 2014; Toohey and Cooper, 2014), such as activating tumor suppressors, modulating ion channels, as well as activating enzymes (Kimura, 2015; Han et al., 2018). Hypoxic stress can disturb the redox equilibrium of intracellular milieu. $\mathrm{H}_{2} \mathrm{~S}_{\mathrm{n}}$, exhibit highly reducing and nucleophilic abilities, are capable of directly scavenging oxidants and intracellular electrophiles. The appropriate checks and balances between $\mathrm{H}_{2} \mathrm{~S}_{\mathrm{n}}$ and reactive oxygen species (ROS) drive the intracellular redox homeostasis. Besides, intracellular $\mathrm{H}_{2} \mathrm{~S}_{n}$ exist intimate relationship and transformation with other bioactive molecule in physiological and pathological processes for further

\footnotetext{
* Corresponding author at: CAS Key Laboratory of Coastal Environmental Processes and Ecological Remediation, Shandong Key Laboratory of Coastal

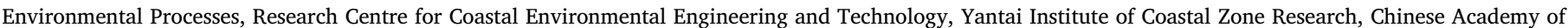
Sciences, Yantai 264003, China.

E-mail address: 1xchen@yic.ac.cn (L. Chen).
} 


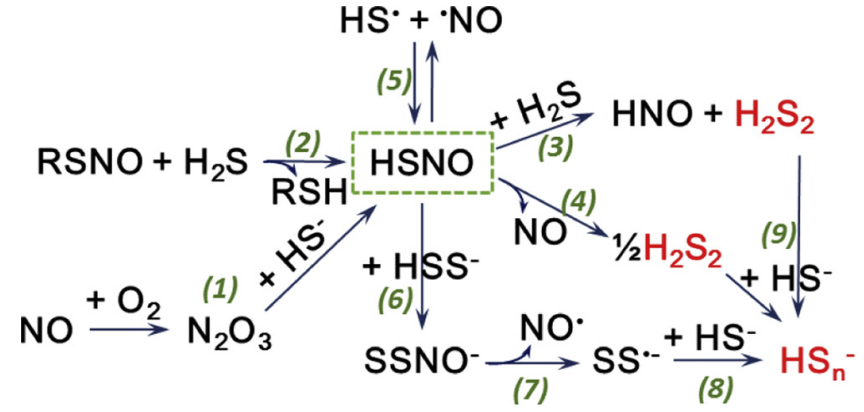

Scheme 1. HSNO-mediated $\mathrm{H}_{2} \mathrm{~S}_{\mathrm{n}}$ generation.

signaling regulation (Lin et al., 2015; Gruhlke and Slusarenko, 2012). Although lots of researches about $\mathrm{H}_{2} \mathrm{~S}_{\mathrm{n}}$ are under active investigation, the biosynthetic pathways and the association with other RSS are still obscure (Cortese-Krott et al., 2015). In cells, $\mathrm{H}_{2} \mathrm{~S}_{\mathrm{n}}$ can be generated from the oxidation of $\mathrm{H}_{2} \mathrm{~S}$ by ROS (Koike et al., 2013), converting from RSSH (Yadav et al., 2015). The reactions between $\mathrm{H}_{2} \mathrm{~S}$ and sulfane sulfurs are also capable of forming $\mathrm{H}_{2} \mathrm{~S}_{n}$ (Chen et al., 2015). The biosynthesis and metabolism of $\mathrm{H}_{2} \mathrm{~S}_{\mathrm{n}}$ are found related to intracellular $\mathrm{H}_{2} \mathrm{~S}$ biosynthesis enzymes, such as cystathionine $\gamma$-lyase (CSE), cystathionine $\beta$-synthetase (CBS), and 3-mercaptopyruvate sulfurtransferase (3MST) (Chen et al., 2016; Kimura, 2014; Kimura, 2019). $\mathrm{H}_{2} \mathrm{~S}$ and $\mathrm{H}_{2} \mathrm{~S}_{\mathrm{n}}$ are redox partners and therefore very likely coexist in biological systems for suppressing oxidative stress together. Recently studies reveal that thionitrous acid (HSNO, the smallest S-nitrosothiol), is also involves in $\mathrm{H}_{2} \mathrm{~S}_{\mathrm{n}}$ generation in the complex RSS network (Kang et al., 2018; Chen et al., 2019; Kimura et al., 2013; Miyamoto et al., 2017). We summarized the relationship between HSNO and $\mathrm{H}_{2} \mathrm{~S}_{n}$ formation in Scheme 1 according to previous studies (Cortese-Krott et al., 2015; Filipovic et al., 2012; Nava et al., 2016). $\mathrm{HS}_{\mathrm{n}}{ }^{-}$is generated from the decomposition of HSNO, whether RSNO or HSSNO, ultimately associated with the decomposition (reactions 2-4, 6-8). Firstly, decomposition of sulfide (reactions $\mathrm{S} 1-11$ ) and $\mathrm{HSNO} / \mathrm{SSNO}^{-}$(reactions 5 , 7) leads to formation of $S^{\cdot-}$ and $S_{2}{ }^{--}$, which could further reacted with one another to form polysulfides (reactions S12-15). There also existed the combination of other RSS and ROS in the complicated physiological and pathological process. However, up to now, there is no direct evidence confirms the process of HSNO-mediated $\mathrm{H}_{2} \mathrm{~S}_{\mathrm{n}}$ formation in living system. Therefore, to development novel chemical tools to observe this process in mitochondria would be very meaningful for understanding of biosynthesis and biological function.

The traditional methods for $\mathrm{H}_{2} \mathrm{~S}_{\mathrm{n}}$ analysis mainly based on UV-vis absorption measurement, mass spectrometry, chromatography methods and so on (Huang et al., 2016; Liu et al., 2014; Sedgwick et al., 2018; Jung et al., 2017). Although these methods are precise and have the advantage of trace detection, they generally require samples with complicated pretreatment. Furthermore, $\mathrm{H}_{2} \mathrm{~S}$ and $\mathrm{H}_{2} \mathrm{~S}_{n}$ may be reversibly converted to one another during the pretreatment process. More importantly, they cannot able to accomplish in situ detection in living cells or in vivo, which greatly limit their application in exploring $\mathrm{H}_{2} \mathrm{~S}_{\mathrm{n}}$ functions in biological systems. Development of novel methods for effective methods for $\mathrm{H}_{2} \mathrm{~S}_{\mathrm{n}}$ detection is desirable. As a powerful method for various species analysis with high sensitivity and selectivity, fluorescence assays technology has boomed in past few years in the field of chemistry, environmental science, clinical medicine and others. Compared with these conventional methods, fluorescence assays based on fluorescence probes are widely applied in imaging of biological reactive species, which profits from their high spatiotemporal resolution, high sensitivity, as well as less invasiveness in living systems (Cheng et al., 2019; Li et al., 2019; Liu et al., 2018; Xu et al., 2015). Having been inspired by pioneering work by Xian in 2014, a series of fluorescence probes for $\mathrm{H}_{2} \mathrm{~S}_{\mathrm{n}}$ have been developed (Table S1) (Liu et al., 2014; Chen et al., 2015; Zeng et al., 2015; Zhang et al., 2016; Shang et al., 2016; Ma et al., 2017; Yang et al., 2018; Fang et al., 2017; Gong et al., 2016; Hou et al., 2016). The previous probes mainly can be divided into two categories according to the reaction mechanism based nucleophilicity and/or reduction ability of $\mathrm{H}_{2} \mathrm{~S}_{\mathrm{n}}$ (Fig. 1A). Based on nucleophilic reaction, two type fluorescence probes DSP and PSP were developed with different response groups for $\mathrm{H}_{2} \mathrm{~S}_{n}$ detection (Chen et al., 2015; Liu et al., 2014). The DSP-types probes adopted 2-fluoro-5-nitrobenzoate as response group. Then the PSP-types probes with phenyl 2-(benzoylthio) benzoate as recognition groups were further developed for $\mathrm{H}_{2} \mathrm{~S}_{n}$ detection. Also, other response units have been adopted for designing

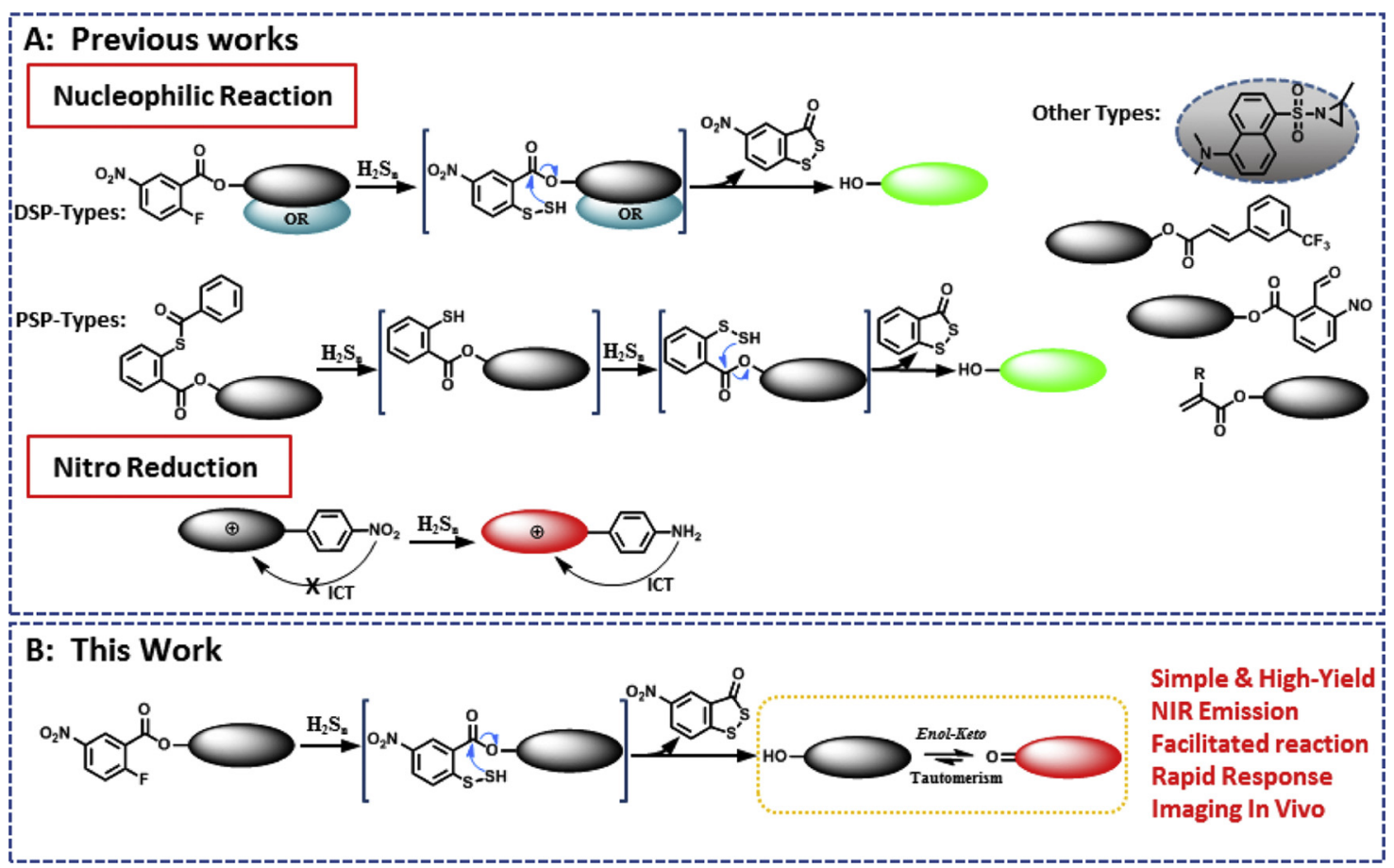

Fig. 1. A: Previous strategy for $\mathrm{H}_{2} \mathrm{~S}_{\mathrm{n}}$-specific fluorescent probes; B: Proposed novel design of the probe for detecting $\mathrm{H}_{2} \mathrm{~S}_{\mathrm{n}}$ in this work. 
$\mathrm{H}_{2} \mathrm{~S}_{\mathrm{n}}$ probes rely on their nucleophilicity. The second type of $\mathrm{H}_{2} \mathrm{~S}_{\mathrm{n}}$ fluorescence probes are designed rely based on the reduction reaction that $\mathrm{H}_{2} \mathrm{~S}_{\mathrm{n}}$ can reduced nitro group (Gong et al., 2016). Although these $\mathrm{H}_{2} \mathrm{~S}_{\mathrm{n}}$ probes have been made great improvement in application, they still present some deficiencies, such as the complex synthesis steps with low yield, and even some probes cannot reach NIR region, which limit realize in situ imaging in deep tissues and in vivo. More importantly, most of the available probes are only simply applied in imaging $\mathrm{H}_{2} \mathrm{~S}_{n}$ in cells, and not used for in depth studying of their biosynthesis and function in living system. Hence, it is still necessary to develop $\mathrm{H}_{2} \mathrm{~S}_{\mathrm{n}^{-}}$ specific fluorescence probes for physiopathology investigation in biological system. In our lab, we have successfully developed several $\mathrm{H}_{2} \mathrm{~S}_{n}$ probes and applied them in imaging cellular $\mathrm{H}_{2} \mathrm{~S}_{\mathrm{n}}$. Recently, a hot topic that HSNO-mediated $\mathrm{H}_{2} \mathrm{~S}_{\mathrm{n}}$ formation has attracted our attention, we intend to design a fluorescent probe featuring mitochondria localization for visual observation of this process and detailed explore biological function under pathological model.

With these considerations in mind, we have designed a NIR probe ((2-fluoro-5-nitrobenzoyl)oxy)-Benzo[e]cyanine (BCy-FN) for in situ visual observation of mitochondrial HSNO-mediated $\mathrm{H}_{2} \mathrm{~S}_{n}$ formation in cells and in vivo of zebrafish under hypoxia stress. The probe is consists of a NIR cyanine fluorophore BCy-Keto scaffold as signalling group and 2-fluoro-5-nitrobenzoate group as recognition group, featuring mitochondria localization. BCy-FN could be briefly synthesized within two steps with low cost and higher total yield (48.26\%). The probe takes advantage of high selectivity, sensitivity and improved response rate towards $\mathrm{H}_{2} \mathrm{~S}_{\mathrm{n}}$. The fluorophore with a characteristic of Enol-Keto tautomerism have stable ketone structure in physiological condition, facilitating the fluorophore release when the probe incubated with $\mathrm{H}_{2} \mathrm{~S}_{n}$ (Fig. 1B). The NIR emission $(727 \mathrm{~nm})$ of the released fluorophore BCyKeto was penetrable and noninvasive which suited for in situ imaging in deep tissue or in vivo. Significantly, we utilized BCy-FN in situ fluorescence imaging of endogenous $\mathrm{H}_{2} \mathrm{~S}_{\mathrm{n}}$ also revealed that another RSS HSNO mediated $\mathrm{H}_{2} \mathrm{~S}_{\mathrm{n}}$ generation no matter in treat-free group or hypoxia conditions.

\section{Experimental}

\subsection{Construction of cell hypoxia/reperfusion models}

Construction of hypoxia/reperfusion (H/R) models: Hypoxia models of $\mathrm{ZF}_{4}$ cells (zebrafish embryonic fibroblast cells) were constructed under $5 \% \mathrm{O}_{2}$ condition for hypoxia $3 \mathrm{~h}$ or $9 \mathrm{~h}, \mathrm{H} / \mathrm{R}$ models were first operated for hypoxia $9 \mathrm{~h}$ and then operated reperfusion for $1 \mathrm{~h}$ with different pre-stimulations. In the reperfusion process, the cells in HSNO group were treated with $100 \mu \mathrm{M}$ HSNO solution and $50 \mu \mathrm{M}$ NaHS during the whole process, the cells in misonidazole group were treated with $40 \mu \mathrm{M}$ racemic misonidazole (inhibitor of GPx) for $30 \mathrm{~min}$ and then cultured as normal in the later $30 \mathrm{~min}$ (Huang et al., 2016), the cells in last group were added $40 \mu \mathrm{M}$ racemic misonidazole and $100 \mu \mathrm{M}$ DL-propargylglycine (PAG, inhibitor of CSE) for $30 \mathrm{~min}$ (Lin et al., 2013). All the tested cells were cultured under other normal conditions. $100 \mu \mathrm{M}$ HSNO solution was prepared via $300 \mu \mathrm{M}$ S-Nitrosoglutathione (GSNO) and $100 \mu \mathrm{M} \mathrm{Na} \mathrm{Na}_{2} \mathrm{~S}$ according reported method (Chen et al., 2019; Filipovic et al., 2012), and the production of HSNO was confirmed via the mass spectrum in Supplementary Information.

\subsection{Establishment of zebrafish hypoxia models}

The zebrafish larvae hypoxia models were established to explore the relation between hypoxia process and the fluctuation of endogenous $\mathrm{H}_{2} \mathrm{~S}_{\mathrm{n}}$. The zebrafish larvae was delicate, to precisely control of temperature and oxygen concentration, 3dpf (days post fertilization) zebrafish hypoxia models were operated in cell incubator. The zebrafish in Group a were directly imaging after anesthetization as control, the zebrafish in Group b were cultured under $8 \%$ oxygen for hypoxia $6 \mathrm{~h}$, the Group c were operated as Group a after pre-incubated with $10 \mu \mathrm{M}$ HSNO solution for $2 \mathrm{~h}$, the zebrafish in Group d were pre-incubated with HSNO solution and then operated as Group b. To evaluate the bioeffect of $\mathrm{H}_{2} \mathrm{~S}_{\mathrm{n}}$ in hypoxia, H\&E slices were good selection for tissue to study pathological levels. Owing to the small size of zebrafish larvae, adult zebrafish hypoxia models were operated as above hypoxia stress in monitorable hypoxia system to make H\&E-stained brain pathology slices. After $6 \mathrm{~h}$ of hypoxia, the zebrafish were quickly anesthetized and then fixed with $4 \%$ paraformaldehyde for $24 \mathrm{~h}$ at room temperature.

\subsection{Fluorescence confocal imaging in cells}

Fluorescent images of cells were obtained via Olympus FV1000 confocal laser scanning microscope (Japan) with an objective lens $(\times 60)$, which equipped with $635 \mathrm{~nm}$ laser to meet probe's excitation wavelength. The emission of BCy-FN was collected from $700 \mathrm{~nm}$ to $800 \mathrm{~nm}$. The commercially available fluorescence dyes MitoTracker ${ }^{\circledR}$ Green FM $\left(\lambda_{\text {em }}=500-580 \mathrm{~nm}, \lambda_{\text {ex }}=488 \mathrm{~nm}\right)$ and Hoechst 33342 $\left(\lambda_{\text {em }}=420-480 \mathrm{~nm}, \lambda_{\text {ex }}=405 \mathrm{~nm}\right)$ were operated according their instructions. The tested cells were cultivated in $20 \mathrm{~mm}$ Petri-dishes for $24 \mathrm{~h}$ to adherence. Before imaging, adding $1 \mathrm{~mL}$ fresh complete medium into culture plates and then incubating the probe BCy-FN and other dyes. The analysis of the co-localization parameters was acquired by Image Pro Plus software, the quantification of cells' fluorescence intensity was obtained by Image $J$ software.

\subsection{Imaging in vivo}

Fluorescence imaging of zebrafish larvae were performed through confocal laser scanning microscope, Olympus FV1000 with an objective lens $(\times 4)$. For fluorescence imaging of exogenous $\mathrm{H}_{2} \mathrm{~S}_{\mathrm{n}}$, 3dpf zebrafish were pretreated with different concentrations of $\mathrm{Na}_{2} \mathrm{~S}_{2}$ for $30 \mathrm{~min}$ and then incubated $5 \mu \mathrm{M} \mathrm{BCy}$-FN for $10 \mathrm{~min}$ at $28^{\circ} \mathrm{C}$ after washing. Before imaging, the zebrafish larvae were anesthetized by tricaine solution (35 mg/L) for $5 \mathrm{~min}$.

Fluorescence imaging of BALB/c mice were taken via IVIS Lumina XRMS Series III (USA, Perkinelmer). The collection windows of excitation and emission were set up as described in paper. Before imaging, the experiment mice were anesthetized by chloral hydrate $(400 \mathrm{mg} / \mathrm{kg})$ through i.p. injection. BCy-FN ( $50 \mu \mathrm{M}, 50 \mu \mathrm{L}$, in DMSO/saline, v/v 1:9) solution was intracranially injected into mice and $2 \%$ isoflurane was used to keeping anesthesia atmosphere during imaging. The quantification of fluorescence intensity of zebrafish and mice was obtained by Image $J$ software.

\subsection{Synthesis of probe BCy-FN}

The synthetic procedures of probe BCy-FN was outlined in Scheme 2. The synthesis of fluorophore Bcy-Keto was reported by our lab (Zhang et al., 2019). 2-Fluoro-5-nitrobenzoic acid (185 mg, $1 \mathrm{mmol}$ ) was dissolved in $15 \mathrm{~mL}$ hydrous $\mathrm{CH}_{2} \mathrm{Cl}_{2}$ at $25^{\circ} \mathrm{C}$ and then the solvent of $10 \mathrm{~mL}$ hydrous $\mathrm{CH}_{2} \mathrm{Cl}_{2}$ containing ethyl chloroglyoxylate $(409.5 \mathrm{mg}$, $3 \mathrm{mmol}$ ) was dropwise added into above system. After $4 \mathrm{~h}$ of stirring, $\mathrm{CH}_{2} \mathrm{Cl}_{2}$ was immediately evaporated under vacuum condition. $\mathrm{BCy}-$ Keto $\left(844 \mathrm{mg}, 1 \mathrm{mmol}\right.$ ) and another $25 \mathrm{~mL}$ fresh hydrous $\mathrm{CH}_{2} \mathrm{Cl}_{2}$ was added into above reaction system and stirred for $12 \mathrm{~h}$ under ambient temperature. The solvent was concentrated and the crude product was purified on silica chromatography (200-300 mush) with methanol and dichloromethane $(\mathrm{v} / \mathrm{v}, 1 / 6)$ as eluents. The brown solid compound (BCy-FN) was obtained, yield $63.5 \% .{ }^{1} \mathrm{H}$ NMR $\left(500 \mathrm{MHz}, \mathrm{CDCl}_{3}-\mathrm{d}_{1}\right) \delta$ (ppm): $8.48-8.41(\mathrm{~m}, 2 \mathrm{H}), 8.07-8.05(\mathrm{~m}, 1 \mathrm{H}), 7.87-7.68(\mathrm{~m}, 7 \mathrm{H})$, 7.51 (m, 2H), $7.39-7.37$ (m, 3H), $7.11-7.09$ (m, 3H), 6.83-6.82 (d, $2 \mathrm{H}), 6.24-6.23(\mathrm{~d}, 2 \mathrm{H}), 3.58-3.55(\mathrm{q}, 2 \mathrm{H}), 3.44-3.42(\mathrm{q}, 2 \mathrm{H}), 1.37$ (s, 12H), $1.26-1.23$ (m, 6H). $\left.{ }^{13} \mathrm{C} \mathrm{NMR} \mathrm{(125} \mathrm{MHz,} \mathrm{CDCl}_{3}-\mathrm{d}_{1}\right) \delta$ (ppm): 181.2, 176.2, 174.5, 160.4, 157.0, 156.9, 156.9, 156.8, 143.7, 143.0, $134.9,128.8,128.7,128.7,128.3,128.2,125.5,123.0,120.5,120.0$, 


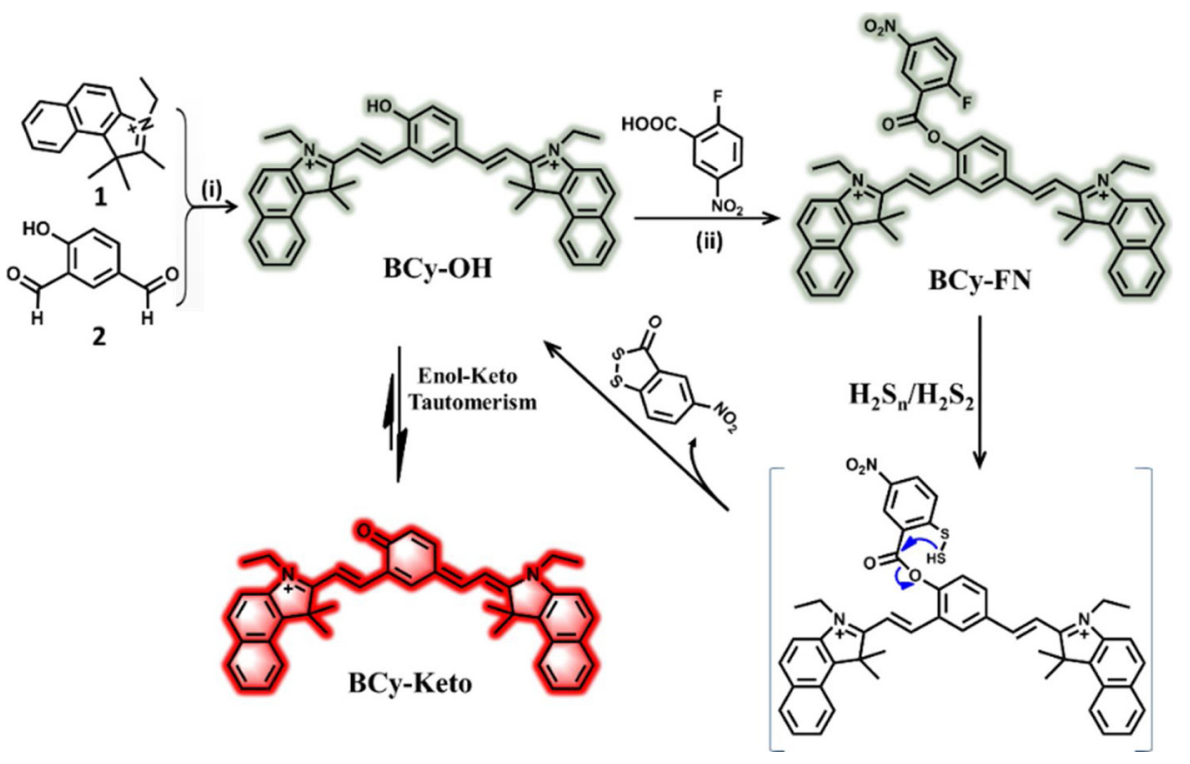

Scheme 2. Synthesis and proposed response mechanism of BCy-FN towards $\mathrm{H}_{2} \mathrm{~S}_{2}$.

116.6, 115.3, 110.8, 109.2, 108.9, 108.6, 90.9, 87.0, 66.0, 65.2, 44.0, 43.3, 26.1, 13.0, 13.0. LC-MS (ESI $\left.{ }^{+}\right): \mathrm{m} / z \quad \mathrm{C}_{49} \mathrm{H}_{44} \mathrm{FN}_{3} \mathrm{O}_{4}{ }^{2+}$ calcd 757.3305, found $[\mathrm{M}-\mathrm{H}]{ }^{+} 756.3232$.

\subsection{Ethics statement}

All surgical operation and procedures were conducted in according with National Guidelines for the Care and Use of Laboratory Animals. The experimental protocols were approved by the Institutional Animal Care and Use Committee in Binzhou Medical University, Yantai, China. Approval Number: No. BZ2014-102R.

\section{Results and discussion}

\subsection{Spectral studies of BCy-FN towards $\mathrm{H}_{2} \mathrm{~S}_{n}$}

In order to confirm the response ability of the probe BCy-FN for $\mathrm{H}_{2} \mathrm{~S}_{\mathrm{n}}$, spectral studies were carried out. $\mathrm{H}_{2} \mathrm{~S}_{\mathrm{n}}$ species commonly include $\mathrm{H}_{2} \mathrm{~S}_{2}, \mathrm{H}_{2} \mathrm{~S}_{3}, \mathrm{H}_{2} \mathrm{~S}_{4}, \mathrm{H}_{2} \mathrm{~S}_{5}$, and so on. $\mathrm{H}_{2} \mathrm{~S}_{2}$ always used as typical delegate of $\mathrm{H}_{2} \mathrm{~S}_{\mathrm{n}}$ due to its simpleness for clear biselectrophilc reaction (Kimura et al., 2013; Liu et al., 2014). So, in this work, we prepared freshly $\mathrm{Na}_{2} \mathrm{~S}_{2}$ solutions as the source of $\mathrm{H}_{2} \mathrm{~S}_{2}$. There exist rapid dynamic conversions among $\mathrm{H}_{2} \mathrm{~S}_{\mathrm{n}}$ species under physiological conditions which are not easy to distinguish them. The physiological concentrations of various $\mathrm{H}_{2} \mathrm{~S}_{\mathrm{n}}$ species have not been reported separately. The spectral properties of probe BCy-FN were examined in simulated physiological solution (10 mM HEPES, pH 7.4). As shown in Fig. 2a and b, with increasing $\mathrm{Na}_{2} \mathrm{~S}_{2}$ concentration $(0-10 \mu \mathrm{M})$, there gradually appear two characteristic absorption peaks of BCy-keto at $499 \mathrm{~nm}$ and $653 \mathrm{~nm}$ $\left(\varepsilon_{653 \mathrm{~nm}}=5.01 \times 10^{4} \mathrm{M}^{-1} \mathrm{~cm}^{-1}\right)$ while the free probe without obvious absorption at $400-800 \mathrm{~nm}$. Simultaneously, fluorescence peak centered at $727 \mathrm{~nm}$ increased owing to the fact that $\mathrm{H}_{2} \mathrm{~S}_{2}$ specifically cuts the ester bond and eliminating d-PET effect. The proposed mechanism was illustrated in Scheme 2. $\mathrm{H}_{2} \mathrm{~S}_{2}$ firstly replaces F-atom of BCy-FN by nucleophilic aromatic substitution (SNAr) and generates an intermediate with free -SH group (Liu et al., 2014). Thereby, the intermediate undergoes intramolecular cyclization which -SH group attacks ester group and releases fluorophore BCy-Keto. In addition, monosubstituted thiols couldn't undergo intramolecular cyclization own to their shortage of adjacent free -SH group (Scheme S1). Inset of Fig. 2b showed a very good linear relationship of the fluorescence intensity and the $\mathrm{H}_{2} \mathrm{~S}_{\mathrm{n}}$ concentration, $\mathrm{F}_{727 \mathrm{~nm}}=-296.2+127126.98 \quad\left[\mathrm{H}_{2} \mathrm{~S}_{\mathrm{n}}\right]$,
$\mathrm{R}^{2}=0.9957$. The theoretical detection limit was calculated to be as low as $46 \mathrm{nM}(3 \sigma / k)$, where $\sigma$ was the standard deviation of blank measurement, and $k$ was the slope of regression equation. The narrower concentration window of fluorescence spectra exhibited in Fig. S2. From time-dependent fluorescence record, the detection of BCy-FN for $\mathrm{H}_{2} \mathrm{~S}_{\mathrm{n}}$ was completed within $2 \mathrm{~min}$ (Fig. $2 \mathrm{c}$ ), this fast response character should attribute to the Enol-Keto tautomerism of product during reaction with $\mathrm{H}_{2} \mathrm{~S}_{\mathrm{n}}$ (Fig. 1B). The result in Fig. 2d demonstrated that only $\mathrm{H}_{2} \mathrm{~S}_{\mathrm{n}}$ caused fluorescence changes as they have the ability to specifically trigger the conversion of $\mathrm{BCy}-\mathrm{FN}$ to $\mathrm{BCy}$-Keto fluorophore.

\section{2. $H_{2} S_{n}$ formation confirmed by spectral studies}

$\mathrm{H}_{2} \mathrm{~S}_{\mathrm{n}}$ derived from $\mathrm{H}_{2} \mathrm{~S}$ in the presence of ROS had been generally recognized (Yu et al., 2015; Gao et al., 2015). BCy-FN was applied in detecting in situ $\mathrm{H}_{2} \mathrm{~S}_{\mathrm{n}}$ formation from $\mathrm{H}_{2} \mathrm{~S}$ and ROS. As shown in Fig. 2e, various ROS didn't induce any fluorescence response to BCy-FN, remarkable fluorescence enhancement were appeared after addition of $\mathrm{H}_{2} \mathrm{~S}$, which indicated $\mathrm{H}_{2} \mathrm{~S}_{\mathrm{n}}$ was formed. $\mathrm{ClO}^{-}$elicited the strongest signals (column 4) indicated that it was the most effective ROS for $\mathrm{H}_{2} \mathrm{~S}_{n}$ formation, which was well-consistent with the reported investigation (Liu et al., 2014; Nagy and Winterbourn, 2010). However, this synthetic pathway of $\mathrm{H}_{2} \mathrm{~S}_{\mathrm{n}}$ was slow which not agrees with rapid metabolism of $\mathrm{H}_{2} \mathrm{~S}_{\mathrm{n}}$ in biological systems. As reported, glutathione peroxidase (GPx) could eliminate ROS via converting $\mathrm{H}_{2} \mathrm{~S}$ to $\mathrm{H}_{2} \mathrm{~S}_{\mathrm{n}}$ (Lin et al., 2015; Yang et al., 2018). Obvious changes in fluorescence signals were obtained after added GPx as catalyst within $15 \mathrm{~min}$, which indicated GPx participated in $\mathrm{H}_{2} \mathrm{~S}_{\mathrm{n}}$ formation process between ROS and $\mathrm{H}_{2} \mathrm{~S}$. In Fig. S3, we also shown the investigation of another biosynthetic pathway of $\mathrm{H}_{2} \mathrm{~S}_{n}$, fluorescence responses of BCy-FN toward $\mathrm{H}_{2} \mathrm{~S}_{\mathrm{n}}$ generated from cysteine and CSE/CBS. Both CSE and CBS enzymes induced the fluorescence changes, which revealed that CSE and CBS could contribute to the generation of $\mathrm{H}_{2} \mathrm{~S}_{\mathrm{n}}$ using cystine as substrate. Compared with CBS, CSE could make a greater contribution for $\mathrm{H}_{2} \mathrm{~S}_{\mathrm{n}}$ generation.

It has been reported that $\mathrm{H}_{2} \mathrm{~S}_{\mathrm{n}}$ is the product of the sulfide/NO interaction, is also intermediates and/or degradation product of HSNO which is generated from the reaction of $\mathrm{H}_{2} \mathrm{~S}$ with RSNO/NO (CorteseKrott et al., 2015; Chen et al., 2019; Nava et al., 2016). There are many fluorescent probes for directly imaging $\mathrm{H}_{2} \mathrm{~S}_{\mathrm{n}}$. However, there is none fluorescent probe available to investigate HSNO-mediated $\mathrm{H}_{2} \mathrm{~S}_{n}$ formation via fluorescence imaging. And the degradation mechanism of HSNO is not clear. As one of the products of reaction between sodium 

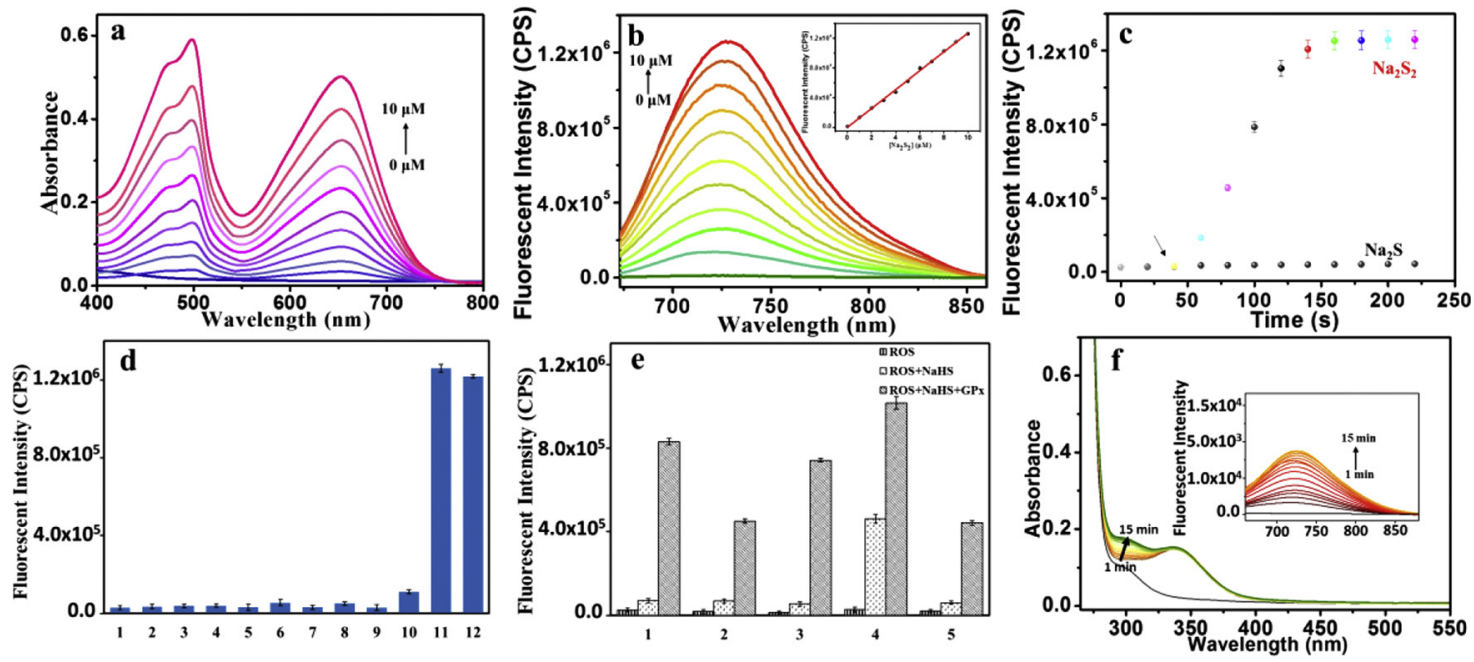

Fig. 2. Spectral studies of BCy-FN towards hydrogen polysulfides. (a) UV-vis absorption spectra and (b) Fluorescence spectra $\left(\lambda_{\text {ex }}=653 \mathrm{~nm}\right)$ of $B C y-F N(10 \mu M)$ incubated with increasing $\mathrm{Na}_{2} \mathrm{~S}_{2}(0-10 \mu \mathrm{M})$ for $5 \mathrm{~min}$ at $37^{\circ} \mathrm{C}$ under simulated biological environment. Inset: Fluorescent intensity of BCy-FN $(727 \mathrm{~nm})$ change as a function of $\mathrm{Na}_{2} \mathrm{~S}_{2}$. (c) Time-dependent fluorescence intensity of probe $(10 \mu \mathrm{M})$ in the presence of $10 \mu \mathrm{M} \mathrm{Na} \mathrm{S}_{2}$ or $\mathrm{Na}_{2} \mathrm{~S}_{2}$. (d) Fluorescence response of BCy-FN (10 $\left.\mu \mathrm{M}\right)$ to various relevant RSS. (1) $100 \mu \mathrm{M}$ Cys; (2) $100 \mu \mathrm{M} \mathrm{Hcy}$; (3) $100 \mu \mathrm{M} \mathrm{GSH}$; (4) $100 \mu \mathrm{M}$ HSNO; (5) $100 \mu \mathrm{M}$ Cystine; (6) $100 \mu \mathrm{M} \mathrm{GSNO;} \mathrm{(7)} 100 \mu \mathrm{M} \mathrm{Na} 2 \mathrm{SO}_{4}$; (8) $100 \mu \mathrm{M}$ $\mathrm{Na}_{2} \mathrm{~S}_{2} \mathrm{O}_{3}$; (9) $100 \mu \mathrm{M} \mathrm{S}_{8}$; (10) $100 \mu \mathrm{M}$ Mixed solution of (1)-(9); (11) $10 \mu \mathrm{M} \mathrm{Na}_{2} \mathrm{~S}_{2}$; (12) $10 \mu \mathrm{M} \mathrm{Na} \mathrm{S}_{4}$. (e) Fluorescence responses of BCy-FN (10 $\mu \mathrm{M}$ ) to various ROS $(50 \mu \mathrm{M})$ in the presence of $\mathrm{H}_{2} \mathrm{~S}(100 \mu \mathrm{M})$ and $\mathrm{GPx}(500 \mathrm{U} / \mathrm{L})$. (1) $\mathrm{H}_{2} \mathrm{O}_{2}$; (2) ${ }^{\circ} \mathrm{OH}$; (3) $\mathrm{O}_{2}{ }^{-}$; (4) $\mathrm{ClO}^{-}$; (5) $\mathrm{ONOO}^{-}$. (f) The reaction of aqueous solutions of sodium sulfide $(10 \mathrm{mM})$ with the NO donor DEA/NO $(1 \mathrm{mM})$ leads to formation of $\mathrm{HS}_{\mathrm{n}}{ }^{-}\left(\lambda_{\max }: 290-300 \mathrm{~nm}\right)$. The blue line represents the spectrum before adding DEA/NO, and the spectra records every 1 min after adding NO. Inset: Fluorescent intensity of BCy-FN for $\mathrm{H}_{2} \mathrm{~S}_{\mathrm{n}}$ formation along with time. (For interpretation of the references to colour in this figure legend, the reader is referred to the web version of this article.)

sulfide and NO, $\mathrm{H}_{2} \mathrm{~S}_{\mathrm{n}}$ has been proposed that has an absorption in the region around $300 \mathrm{~nm}\left(\lambda_{\mathrm{ab}}=290-300 \mathrm{~nm}\right)$. To confirm the assumption of HSNO-mediated $\mathrm{H}_{2} \mathrm{~S}_{\mathrm{n}}$ generation, we performed spectral experiments to confirm the reaction of $\mathrm{NO}$ and $\mathrm{H}_{2} \mathrm{~S}$ (Cortese-Krott et al., 2015; Chen et al., 2019). As shown in Fig. 2f, increased absorption around $300 \mathrm{~nm}$ was observed when $10 \mathrm{mM} \mathrm{Na} \mathrm{Na}_{2} \mathrm{~S}$ and $1 \mathrm{mM}$ DEA NONOate (DEA/NO, one NO donor) are mixed together along with reaction time $(1-15 \mathrm{~min})$. Subsequently, the probe BCy-FN was used to investigate HSNO-mediated $\mathrm{H}_{2} \mathrm{~S}_{\mathrm{n}}$ formation in the reaction. The fluorescence emission did change at $727 \mathrm{~nm}$ along with reaction time (inset). These matched with the above hypothesis that HSNO- mediated $\mathrm{H}_{2} \mathrm{~S}_{n}$ generation in the sulfide/NO interaction. This also indicated that our results are consistent with the reported work, which described $\mathrm{H}_{2} \mathrm{~S}_{\mathrm{n}}$ were one significant degradation products of HSNO (Cortese-Krott et al., 2015).

\subsection{Detection and sub-location in cells}

To assess the biocompatibility of the probe, we measured the viability of $\mathrm{ZF}_{4}$ cells in presence of BCy-FN $(0-80 \mathrm{mM})$ via MTT assay. The experimental results illustrated in Fig. S4, the high cells viability explains the low cytotoxicity of the BCy-FN. Subsequently, we planned to verify potential application of probe BCy-FN for sensing $\mathrm{H}_{2} \mathrm{~S}_{\mathrm{n}}$ fluctuation in living cells. After being incubated with $2 \mu \mathrm{M}$ BCy-FN for $10 \mathrm{~min}$, RAW264.7 cells (Fig. 3a1) and $\mathrm{ZF}_{4}$ cells (Fig. 3a2) both emitted modest fluorescence $\left(\lambda_{\mathrm{em}}=700-800 \mathrm{~nm}, \lambda_{\mathrm{ex}}=635 \mathrm{~nm}\right)$. If pretreated cells with $15 \mu \mathrm{M} \mathrm{Na}_{2} \mathrm{~S}_{2}$ for $20 \mathrm{~min}$, the strong fluorescence were observed in Fig. 3b. To examine the application of probe in endogenous $\mathrm{H}_{2} \mathrm{~S}_{n}$ detection, $1 \mu \mathrm{g} / \mathrm{mL}$ lipopolysaccharide (LPS, induced CSE mRNA overexpression) was added for $16 \mathrm{~h}$ to enhance the activity of CSE in cells (Zhu et al., 2010). As exhibited in Fig. 3c, the cells stimulated by LPS expressed more remarkable fluorescence intensity than the cells in control group. However, synchronous adding PAG was not stimulated cells to generate $\mathrm{H}_{2} \mathrm{~S}_{n}$ (Fig. 3d) (Lin et al., 2013). These confocal fluorescence images certified that the probe BCy-FN could sensitively image endogenous $\mathrm{H}_{2} \mathrm{~S}_{\mathrm{n}}$ in situ in living cells.

Co-staining experiments were performed to verify the mitochondrial distribution potential of BCy-FN in cells. It's reported that the intracellular CSE enzyme is mainly localized in the cytosol, few in the mitochondria (Kimura, 2014; Gao et al., 2018; Fu et al., 2012). And CSE could transfer from cytosol to mitochondria accompanied by increasing of intracellular calcium when cells exposed to A23187 (one calcium ionophore, induce CSE mitochondrial translocation) (Fig. 3n) (Gao et al., 2018; Fu et al., 2012). The cells were pre-incubated with $1 \mu \mathrm{M}$ A23187 for $24 \mathrm{~h}$ to transfer CSE into mitochondria. The commercial mitochondrial dye MitoTracker ${ }^{\circledast}$ Green FM (Fig. 3f) and nucleus dye Hoechst 33342 (Fig. 3g) were co-incubated with BCy-FN (Fig. 3e) in RAW 264.7 cells. As shown in Fig. 3i-k, the red channel overlaid well with the green channel and shown a high Pearsons's correlation coefficient $\mathrm{Rr}=0.94$. In Fig. 3o, the intensity profile of BCy-FN and MitoTracker $^{\circledR}$ Green FM exhibited excellent anastomosis while blue channel displayed no overlap with red channel. The results indicated that our probe BCy-FN could cluster in mitochondria and stain mitochondria $\mathrm{H}_{2} \mathrm{~S}_{\mathrm{n}}$. As shown in Fig. S7, the probe BCy-FN displayed powerful application in imaging of mitochondrial $\mathrm{H}_{2} \mathrm{~S}_{\mathrm{n}}$ fluctuations in different cell lines, including SHSY5Y, A549, SMMC-7721, U87, HEK293 and HL7702. The flow cytometry assays of fluorescence intensities before (gray) and after (red) adding $\mathrm{Na}_{2} \mathrm{~S}_{2}$ were performed in Fig. S7c, the results were consistent with the fluorescence intensities of cells imaging via confocal microscopy. All of these confirmed the applicability of our probe BCy-FN for in situ sensing $\mathrm{H}_{2} \mathrm{~S}_{\mathrm{n}}$ in living cells.

\subsection{Investigation of $\mathrm{H}_{2} \mathrm{~S}_{n}$ generation via multiple bio-pathways}

Encouraged by above application of the probe, we wondered if $\mathrm{BCy}$ FN could be responsible for $\mathrm{H}_{2} \mathrm{~S}_{\mathrm{n}}$ which generated from multiple biopathways in complex biological systems. First, $\mathrm{H}_{2} \mathrm{~S}_{\mathrm{n}}$ generated from the biosynthetic pathway of ROS and $\mathrm{H}_{2} \mathrm{~S}$ was visualized through $\mathrm{H}_{2} \mathrm{~S}_{\mathrm{n}}$ specific recognition probe $\mathrm{BCy}-\mathrm{FN}$ in RAW 264.7 and $\mathrm{ZF}_{4}$ cells (Fig. 4a-e). The hypothesis that $\mathrm{H}_{2} \mathrm{~S}_{\mathrm{n}}$ may be generated by HSNOmediated interaction between $\mathrm{H}_{2} \mathrm{~S}$ and $\mathrm{RSNO} / \mathrm{NO}$, and then was examined in $\mathrm{ZF}_{4}$ cells (Fig. $4 \mathrm{f}-\mathrm{i}$ ). The production of HSNO in HSNO solution was confirmed via the mass spectrum Fig. S8 (Kang et al., 2018; Filipovic et al., 2012; Islam et al., 2017). As shown in Fig. 4a-e, no 

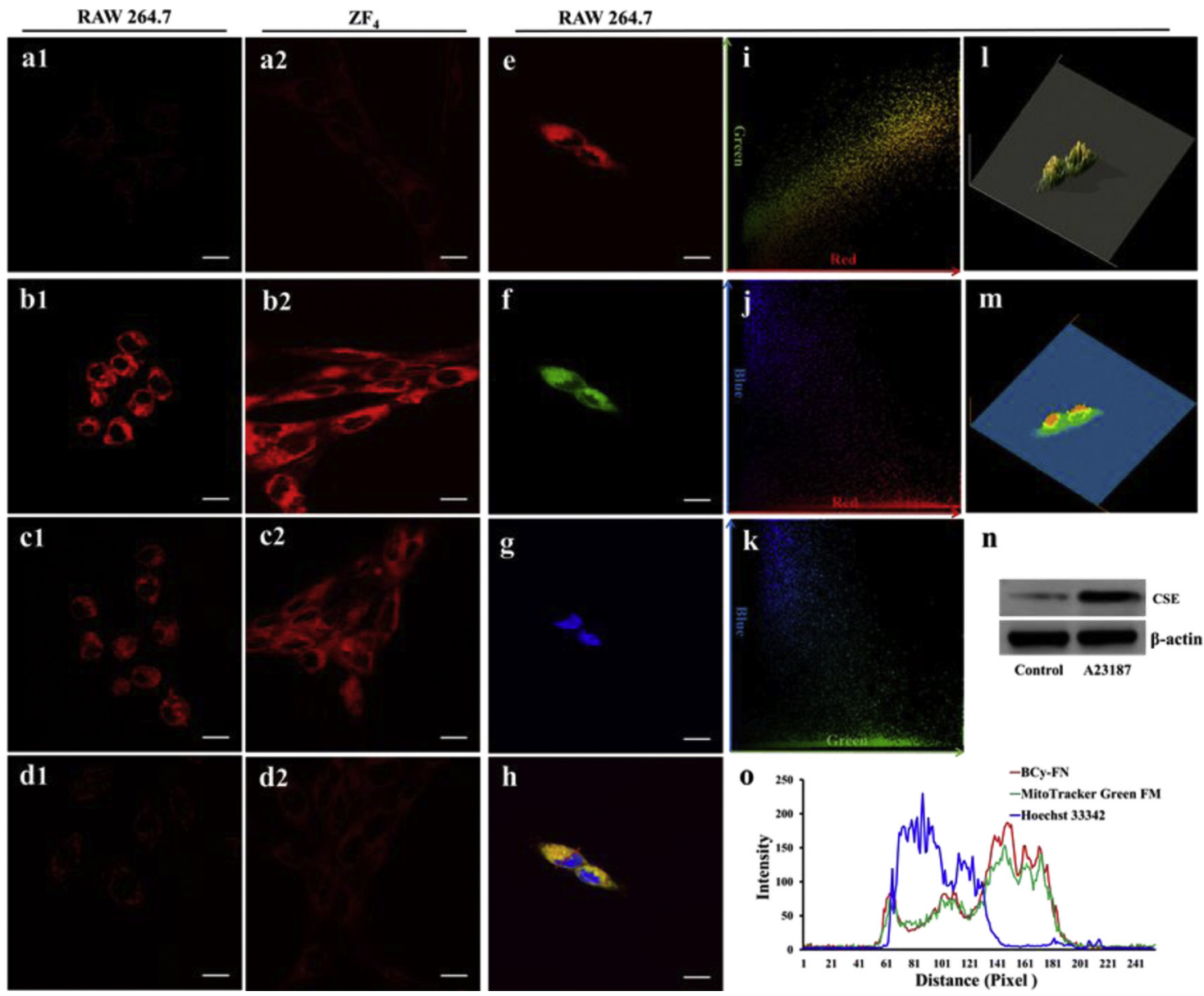

Fig. 3. Confocal imaging of $\mathrm{H}_{2} \mathrm{~S}_{\mathrm{n}}$ in RAW 264.7 (a1-d1) and $\mathrm{ZF}_{4}$ cells (a2-d2) exposed to different stimulation with BCy-FN ( $\left.2 \mu \mathrm{M}\right)$ and sublocation of BCy-FN in RAW 264.7 cells. Scale bar: $10 \mu \mathrm{m}$. (a) Cells were treated with BCy-FN for 10 min. (b) Pretreated cells with $\mathrm{Na}_{2} \mathrm{~S}_{2}(15 \mu \mathrm{M})$ for 20 min and then incubated with BCy-FN. (c) After stimulated with LPS $(1 \mu \mathrm{g} / \mathrm{mL})$ for $16 \mathrm{~h}$, the cells were incubated with BCy-FN for $10 \mathrm{~min}$. (d) Manipulated as (c) but additionally added PAG (100 $\mu \mathrm{M}$, 30 min). The cells for mitochondrial multicolor colocalization were pre-stained with BCy-FN (red channel, $2 \mu \mathrm{M}, 10 \mathrm{~min}$ ) (e), MitoTracker ${ }^{\oplus} \mathrm{Green}$ FM (green channel, $1 \mu \mathrm{g} / \mathrm{mL}$, $15 \mathrm{~min}$ ) (f), Hoechst 33342 (bule channel, $1 \mu \mathrm{g} / \mathrm{mL}, 30 \mathrm{~min})(\mathrm{g})$ at $37^{\circ} \mathrm{C}$. (h) Overlay image of red, green and blue channels. (i)-(k) Co-localization areas of red and green channels, red and blue channels, green and blue channels. (l)-(m) Perspective observation of multicolor co-localization. (n) Western blot analysis of mitochondrial translocation of CSE induced by A23187. (o) Intensity profile of interesting regions (red arrow) in overlapped images in (h). (For interpretation of the references to colour in this figure legend, the reader is referred to the web version of this article.)

matter RAW 264.7 or $\mathrm{ZF}_{4}$ cells, there is no fluorescence signal when the cells merely incubated with BCy-FN and feeble fluorescence was observed after pretreated with NaHS. Obviously, the fluorescence intensity was enhanced significantly when cells sequentially incubated with $1 \mu \mathrm{g} / \mathrm{mL}$ 12-myristate-13-acetate (PMA, stimulated overproduction of ROS) for $1 \mathrm{~h}$ and NaHS (Yu et al., 2015). In order to demonstrate $\mathrm{H}_{2} \mathrm{~S}_{n}$ generation pathway of ROS and $\mathrm{H}_{2} \mathrm{~S}$, simultaneously stimulated cells with $\mathrm{N}$-acetylcysteine (NAC, a powerful ROS scavenger) induced a dramatic fluorescence signal recession (Fig. 4d) (Yuan et al., 2015). And once added racemic misonidazole to inhibit GPx activity, $\mathrm{H}_{2} \mathrm{~S}_{\mathrm{n}}$ generation also was majorly suppressed (Fig. 4e). This experiment demonstrated that $\mathrm{H}_{2} \mathrm{~S}_{\mathrm{n}}$ is generated from the reaction of ROS and $\mathrm{H}_{2} \mathrm{~S}$ catalyzed by GPx in RAW 264.7 and $\mathrm{ZF}_{4}$ cells, which approved the mechanism that GPx scavenged ROS through oxidation of $\mathrm{H}_{2} \mathrm{~S}$. And BCy-FN was able to in situ image $\mathrm{H}_{2} \mathrm{~S}_{n}$ generation via biopathway of ROS and $\mathrm{H}_{2} \mathrm{~S}$.

Compared with the control group, the group treatment with HSNO solution induced modest fluorescence enhancement in cells (Fig. 4f). Intriguingly, extra $50 \mu \mathrm{M}$ NaHS further added into HSNO-incubated cells would exhibit partly increasing fluorescence signal (Fig. 4g), which could be explained by the reaction 3, 4, and 9 in Scheme 1 (Filipovic et al., 2012). To further explore HSNO-mediated $\mathrm{H}_{2} \mathrm{~S}_{\mathrm{n}}$ generation from $\mathrm{H}_{2} \mathrm{~S}$ and RSNO/NO, the cells treatment with DEA/NO and
NaHS as another biosynthesis way of HSNO to image intracellular $\mathrm{H}_{2} \mathrm{~S}_{n}$ levels via BCy-FN. The faint fluorescence indicated lower $\mathrm{H}_{2} \mathrm{~S}_{n}$ levels. The cells also showed a certain fluorescence enhancement (Fig. 4i) when constantly cultured the cells with NaHS after first period of incubation. However, the signal change induced by this pathway was significantly weaker than that of HSNO solution treatment assay, which maybe attribute to the step of HSNO generation in the reaction between $\mathrm{NO}$ and $\mathrm{H}_{2} \mathrm{~S}$ (reaction 1 in Scheme 1). Furthermore, the fluorescence intensities of imaging were quantified in Fig. $4 \mathbf{j}$, which directly reflected the fluctuation of intracellular $\mathrm{H}_{2} \mathrm{~S}_{\mathrm{n}}$ generation. No matter inside or outside the cells, there are many biosynthesis pathways for HSNO and $\mathrm{H}_{2} \mathrm{~S}_{\mathrm{n}}$, and most of which are enzymatic reactions. Given biological yields depended on related-enzymes (e.g. CSE, CBS), which are mainly localized in the cytosol of cells (Kimura, 2014; Filipovic et al., 2012; Ida et al., 2014), the effects of extracellular HSNO and $\mathrm{H}_{2} \mathrm{~S}_{\mathrm{n}}$ on the experiment are not considered. All these solid results indicated that $\mathrm{H}_{2} \mathrm{~S}_{\mathrm{n}}$ indeed generated from HSNO-mediated reaction between $\mathrm{H}_{2} \mathrm{~S}$ and $\mathrm{RSNO} / \mathrm{NO}$, and the probe $\mathrm{BCy}-\mathrm{FN}$ is a powerful tool for exploring the biosynthetic pathway of $\mathrm{H}_{2} \mathrm{~S}_{\mathrm{n}}$ generation by in situ imaging (Cortese-Krott et al., 2015; Chen et al., 2019). 


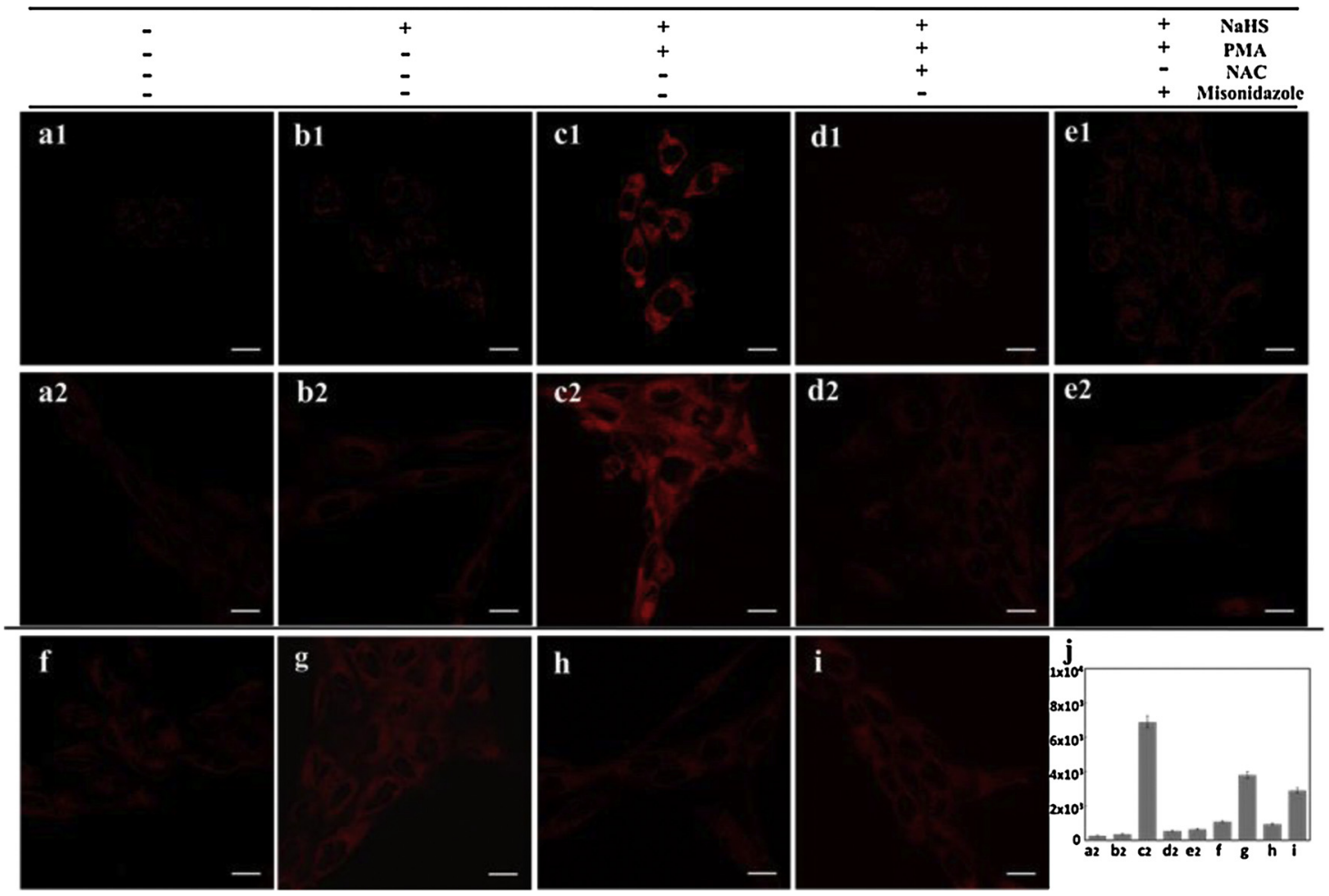

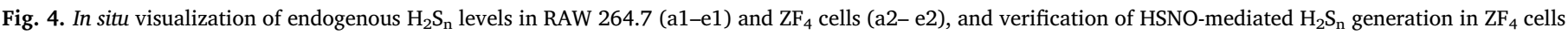

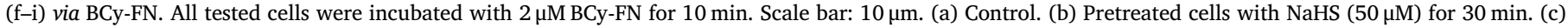

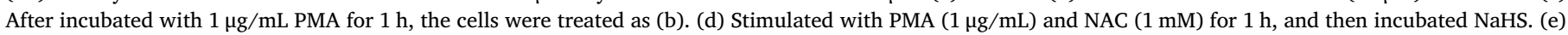

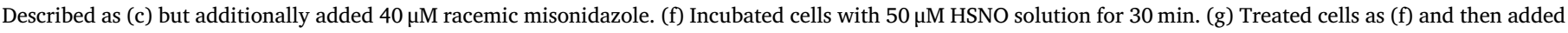

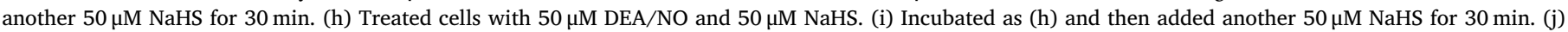
Mean fluorescence intensity of cell imaging in a2-i.

\subsection{Assessment the effects of HSNO-mediated $\mathrm{H}_{2} \mathrm{~S}_{n}$ on hypoxia/reperfusion induced mitochondrial damage}

Since the probe BCy-FN had been assisted imaging HSNO-mediated $\mathrm{H}_{2} \mathrm{~S}_{\mathrm{n}}$ generation in mitochondria, we next evaluated the effects of mitochondrial $\mathrm{H}_{2} \mathrm{~S}_{\mathrm{n}}$ on $\mathrm{H} / \mathrm{R}$ induced damage. It has been examined that HSNO solution prepared with GSNO and $\mathrm{H}_{2} \mathrm{~S}$ can generate a few $\mathrm{H}_{2} \mathrm{~S}_{\mathrm{n}}$ in cells, and the intracellular $\mathrm{H}_{2} \mathrm{~S}_{\mathrm{n}}$ can be significantly obtained through BCy-FN when $\mathrm{H}_{2} \mathrm{~S}$ continues to incubation. Therefore, we constructed a hypoxia reperfusion model of $\mathrm{ZF}_{4}$ cells and evaluated the effects of HSNO-mediated production of $\mathrm{H}_{2} \mathrm{~S}_{\mathrm{n}}$ on cell damage in this process. As shown in Fig. 5A, from fluorescence imaging, mitochondrial $\mathrm{H}_{2} \mathrm{~S}_{n}$ was gradually enhanced as hypoxia time was prolonged. The decreasing mitochondrial membrane potential $\left(\Delta \Psi_{m}\right)$ as one biomarker of early apoptosis was measured by 5,5',6,6'-tetrachloro-1,1',3,3'- tetraethylimidacarbocyanine (JC-1) via flow cytometry analysis (FCA) (Zhang et al., 2019). The ratio of JC-1 (red/green) depended on its ratio of dimer or monomer, that is, cellular apoptosis ratio. The lower ratio (red/green), the lower $\Delta \Psi_{m}$, the more serious apoptosis. In Fig. 5B and C, FCA results of Annexin V/7-AAD gradually aggravated and the ratio of JC-1 (red/green) decreased simultaneously, which indicated apoptosis gradually aggravated along with cells $\mathrm{H} / \mathrm{R}$ process.

Furthermore, the fluorescence of $\mathrm{H}_{2} \mathrm{~S}_{\mathrm{n}}$ traced by BCy-FN was increasing when the cells reperfusion $1 \mathrm{~h}$, and the FCA data of apoptosis

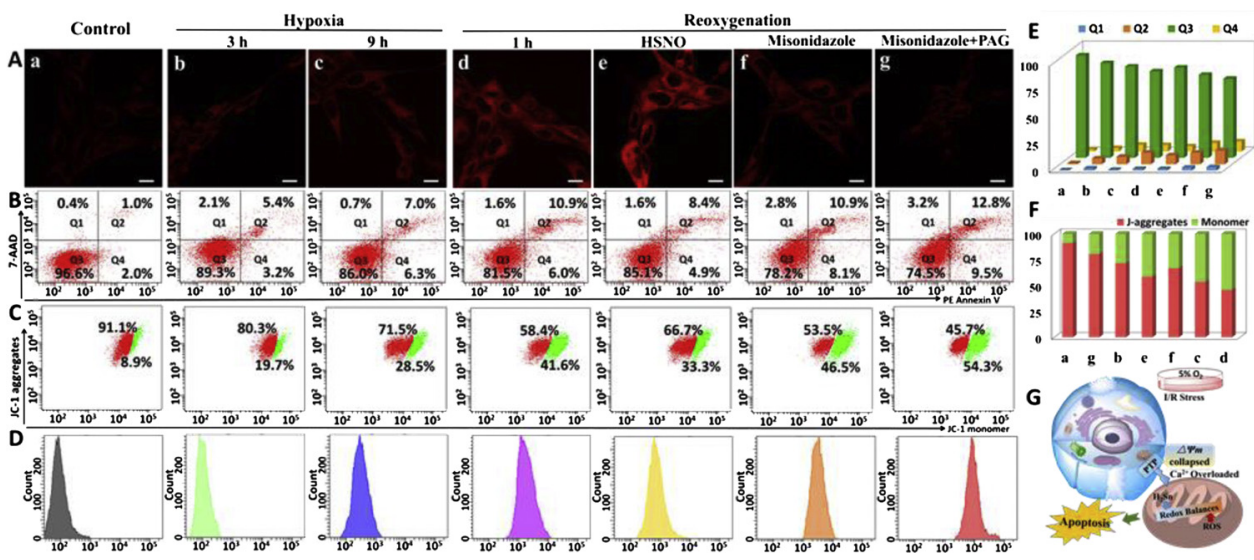

Fig. 5. Evaluation the relationship between $\mathrm{H}_{2} \mathrm{~S}_{\mathrm{n}}$ levels and mitochondrial related hypoxia damage during hypoxia reperfusion process in $\mathrm{ZF}_{4}$ cells. A: Confocal fluorescence images of control (a), different hypoxia times under $5 \%$ $\mathrm{O}_{2}$ condition ( $\mathrm{b}$ and $\mathrm{c}$ ), reperfusion $1 \mathrm{~h}$ treated with different stimulations $(d-g)$. Scale bar: $10 \mu \mathrm{m}$. B: FCA of apoptosis analyzed by Annexin V/7-AAD, Q1-Q4: necrotic, late apoptosis, viable, early apoptosis. C: $\Delta \Psi \mathrm{m}$ assays. D: Fluorescence intensity of ROS tested by Hydro-IR-783 via FCA. E-F: The histograms showed FCA of apoptosis analysis and $\triangle \Psi \mathrm{m}$ in Fig. 5B-C. G: The proposed schematic mechanism of mitochondrial related hypoxia damage and $\mathrm{H}_{2} \mathrm{~S}_{\mathrm{n}}$ antioxidant reaction under $\mathrm{H} / \mathrm{R}$ stress in living cells. (For interpretation of the references to colour in this figure text, the reader is referred to the web version of this article.) 
and $\Delta \Psi_{m}$ indicated the cellular state were worse (group d). In order to examine the effect of $\mathrm{H}_{2} \mathrm{~S}_{\mathrm{n}}$ during cell $\mathrm{H} / \mathrm{R}$ process, the cells in group e were pretreated with $100 \mu \mathrm{M}$ HSNO solution and $50 \mu \mathrm{M}$ NaHS while reperfusion. As expected, the fluorescence intensity was stronger than any other groups, which supported that HSNO-mediated $\mathrm{H}_{2} \mathrm{~S}_{n}$ was really generated in the $\mathrm{ZF}_{4}$ cells. However, racemic misonidazole, the inhibitor of GPx was once added after hypoxia process, the fluorescence signal of $\mathrm{H}_{2} \mathrm{~S}_{n}$ was down-regulated discernibly (group f). As various biopathways of $\mathrm{H}_{2} \mathrm{~S}_{\mathrm{n}}$ were blocked in the last group after extra addition of racemic misonidazole and PAG, the fluorescence intensity exhibited a more serious decline. To compare the cellular state of these groups during reperfusion, assisted with FCA data in Fig. 5B and C, HSNO treated group not only displayed higher $\Delta \Psi_{m}$ but also possessed weaker apoptosis than treated-free reperfusion group. However, two groups of lower $\mathrm{H}_{2} \mathrm{~S}_{\mathrm{n}}$ levels emerged aggravated damage gradient with the same $\mathrm{H} / \mathrm{R}$ time. Fig. 5E and F visually presented the FCA results of apoptosis and $\Delta \Psi_{m}$. In the Fig. S9, the FCA results exhibited that $\mathrm{Ca}^{2+}$ gradually overloaded with the extension of hypoxia time/reperfusion/inhibition of $\mathrm{H}_{2} \mathrm{~S}_{\mathrm{n}}$. The intracellular ROS levels tested by Hydro-IR-783 (one reported ROS fluorescent probe) were matched with the apoptosis fluctuations (Fig. 5D) (Kundu et al., 2009), which maybe attribute to the consumption of ROS by reductant $\mathrm{H}_{2} \mathrm{~S}_{\mathrm{n}}$.

The proposed schematic of cellular damage under $H / R$ stress was displayed in Fig. 5G. H/R process caused excessive uptake of $\mathrm{Ca}^{2+}$, opening of permeability transition pore (PTP) and later collapse of $\Delta \Psi_{m}$. Whereafter, mitochondrial redox was imbalance and increasing $\mathrm{H}_{2} \mathrm{~S}_{\mathrm{n}}$ was not enough to resist more ROS and eventually apoptosis occurred. If the cells pretreatment with HSNO solution, the imbalance of redox and damages were suppressed partly, which indicated that HSNOmediated $\mathrm{H}_{2} \mathrm{~S}_{\mathrm{n}}$ generation attributed to the protective roles in hypoxia process. While pre-incubated with inhibitor of $\mathrm{H}_{2} \mathrm{~S}_{\mathrm{n}}$ synthases, the cells possessed more serious $\Delta \Psi_{m}$ collapsed and $\mathrm{Ca}^{2+}$ overloaded and apoptosis were aggravated deservedly. All these results further confirm the fact that BCy-FN has the ability of in situ imaging mitochondrial $\mathrm{H}_{2} \mathrm{~S}_{\mathrm{n}}$ and assisting evaluated the cytoprotection of $\mathrm{H}_{2} \mathrm{~S}_{\mathrm{n}}$ in $\mathrm{H} / \mathrm{R}$ process.

\subsection{The ability of BCy-FN to examine $\mathrm{H}_{2} \mathrm{~S}_{n}$ in zebrafish}

Afterwards, further exploratory efforts were made to investigate if BCy-FN could be used for in situ imaging $\mathrm{H}_{2} \mathrm{~S}_{\mathrm{n}}$ in zebrafish. To make sure the security of BCy-FN for imaging endogenous $\mathrm{H}_{2} \mathrm{~S}_{n}$ in vivo, the biocompatibilities assay of BCy-FN were executed (Fig. S10). In the control zebrafish, nearly no fluorescence was observed after incubation with BCy-FN (Fig. S11). However, the fluorescence was enhanced in a different extent when the zebrafish was pretreated with different concentrations of $\mathrm{Na}_{2} \mathrm{~S}_{2}$ for $30 \mathrm{~min}$. Enhanced fluorescence imaging in $\mathrm{Na}_{2} \mathrm{~S}_{2}$-loaded zebrafish indicated that BCy-FN could react with $\mathrm{H}_{2} \mathrm{~S}_{n}$ inside the zebrafish.

With the sensing ability of BCy-FN for $\mathrm{H}_{2} \mathrm{~S}_{n}$ verification in zebrafish larvae, we last established zebrafish hypoxia models and evaluated the bio-effect of HSNO-induced $\mathrm{H}_{2} \mathrm{~S}_{\mathrm{n}}$ in zebrafish hypoxia process. 3pdf zebrafish were cultured under hypoxia state in the absence (Fig. 6 Group $a$ and $b$ ) and presence of $10 \mu \mathrm{M}$ HSNO solution (Fig. 6 Group c and d). All the imaging zebrafish larvae were anesthetized by tricaine solution $(35 \mathrm{mg} / \mathrm{L})$ before imaging. As exhibited in Fig. 6A, zebrafish larvae in Group b displayed feeble fluorescence signal compared with the control Group a. The slight increasing of fluorescence intensity indicated the enhancement of $\mathrm{H}_{2} \mathrm{~S}_{\mathrm{n}}$ level in the zebrafish during hypoxia process. To assessment the bioeffect of $\mathrm{H}_{2} \mathrm{~S}_{\mathrm{n}}$ under hypoxia conditions, we first established the relative control Group $\mathrm{c}$ after treatment with the HSNO solution. And HSNO-pretreated hypoxia model was also constructed in Group d, which exhibited discernible enhancement of fluorescence imaging in comparison with control Group a and relative control Group c. The quantification of zebrafish's fluorescence intensity was exhibited in Fig. S12. The in situ imaging of $\mathrm{H}_{2} \mathrm{~S}_{\mathrm{n}}$ via BCy-FN in zebrafish larvae demonstrated that HSNO could also cause endogenous
$\mathrm{H}_{2} \mathrm{~S}_{\mathrm{n}}$ changes in zebrafish hypoxia model.

Considering that hypoxia process would result in irreversible damage to the brain, we were going to explore the extent of brain damage of zebrafish via H\&E-stained brain tissue slices and further evaluate the bioeffect of HSNO-mediated $\mathrm{H}_{2} \mathrm{~S}_{\mathrm{n}}$ generation. However, it was not easy to make brain slices of zebrafish larvae owning to them small size. Hence, we adopted adult zebrafish to make H\&E-stained brain pathology slices after operating same hypoxia stress to observe the damage tendency. From the results of H\&E slices in Fig. 6B, the degree of damage was Group b > Group d > Group a > Group c. Magnification H\&E-stained slides of zebrafish mesencephalon exhibited that the cells in control group were arranged neatly without vacuolar, stained uniform; the cells in hypoxia group were irregular with contracted edges, stained deeply and accompanied by condensed cytoplasm and wrinkled nucleus, as shown by the black arrows in the Fig. 6B. Under same hypoxia condition, HSNO-pretreated zebrafish hypoxia group partly reduced the brain injury (Group $d<$ Group b) with relaxative condensed cytoplasm. The inevitable damage for zebrafish would occur during extracted, anaesthetized, and fixed sample. This match with the result of relative control Group c, HSNO-mediated $\mathrm{H}_{2} \mathrm{~S}_{\mathrm{n}}$ alleviated the unavoidable systematic damage of zebrafish in (Group c < Group a), which attributed to the protective effect of $\mathrm{H}_{2} \mathrm{~S}_{\mathrm{n}}$ for hypoxia damage. HSNO-mediated generation of $\mathrm{H}_{2} \mathrm{~S}_{\mathrm{n}}$ played bio-protect for zebrafish during hypoxia. And our probe BCy-FN assisted to sense $\mathrm{H}_{2} \mathrm{~S}_{n}$ fluctuations via imaging real-time and in situ imaging.

\subsection{Visualization of HSNO-mediated $\mathrm{H}_{2} \mathrm{~S}_{n}$ levels in vivo}

Known for the characteristics of noninvasiveness, anti-interferences, and high tissue penetration, NIR fluorescence probes have great superiorities in visualization imaging in vivo. Next, we investigated the practicability of BCy-FN for imaging HSNO-mediated $\mathrm{H}_{2} \mathrm{~S}_{n}$ in BALB/c mice (Fig. 7). The mice in Fig. 7a were injected with BCy-FN for 20 min as control. To in situ image HSNO-mediated $\mathrm{H}_{2} \mathrm{~S}_{\mathrm{n}}$ in vivo, HSNO solution were pre-injected in Fig. $7 \mathrm{~b}$ mice for $30 \mathrm{~min}$ and then given BCy-FN. Although the fluorescence imaging had changed, the alteration was extremely tiny. In another group of HSNO solution injected mice (Fig. 7 c), thirty minutes later, additional NaHS $(250 \mu \mathrm{M}, 100 \mu \mathrm{L})$ were added into the peritoneal cavity of mice. Intriguingly, contrast with Fig. $7 \mathrm{~b}$, a considerable fluorescence enhancement was observed in Fig. $7 \mathrm{c}$ if the mice were further injected with NaHS. In order to verify the probe was capable of imaging different concentrations $\mathrm{H}_{2} \mathrm{~S}_{\mathrm{n}}$ in vivo, the mice injected with $\mathrm{Na}_{2} \mathrm{~S}_{2}(50 \mu \mathrm{M}, 100 \mu \mathrm{L})$ for $30 \mathrm{~min}$ had induced stronger fluorescence enhancement in Fig. 7d. Fig. 7e intuitively exhibited the average values of total photon flux in Fig. 7a-d, these results revealed that the NIR emission makes BCy-FN possible to penetrate mice and imaging HSNO-mediated $\mathrm{H}_{2} \mathrm{~S}_{\mathrm{n}}$ levels successfully.

\section{Conclusions}

In summary, we have successfully developed NIR fluorescent probe BCy-FN for exploring HSNO-mediated $\mathrm{H}_{2} \mathrm{~S}_{\mathrm{n}}$ generation in living cells and in vivo, and first provided visual evidences for observation of $\mathrm{H}_{2} \mathrm{~S}_{\mathrm{n}}$ generation in different biological pathways. The probe BCy-FN is composed of fluorescence transducer BCy-Keto and response unit 2fluoro-5-nitrobenzoic acid through briefly synthetic route, featuring mitochondria localization. This probe displays high selectivity and sensitivity to $\mathrm{H}_{2} \mathrm{~S}_{\mathrm{n}}$ without interferences from ROS, RSS, and other analytes in physiological environment and multiple cells. In both $\mathrm{ZF}_{4}$ cells $\mathrm{H} / \mathrm{R}$ models and zebrafish hypoxia models, BCy-FN has been successfully applied to in situ imaging $\mathrm{H}_{2} \mathrm{~S}_{\mathrm{n}}$ changes including HSNO mediated $\mathrm{H}_{2} \mathrm{~S}_{n}$ generation. We find that up-regulated $\mathrm{H}_{2} \mathrm{~S}_{\mathrm{n}}$ emerged in the course of $\mathrm{ZF}_{4}$ cells and zebrafish hypoxia, and the results from flow cytometry and H\&E sections exhibit HSNO-mediated $\mathrm{H}_{2} \mathrm{~S}_{n}$ resists the damage caused by hypoxia stress. Penetration imaging $\mathrm{H}_{2} \mathrm{~S}_{n}$ by BCy-FN in mice peritoneal cavity suggests that our probe has excellent NIR 


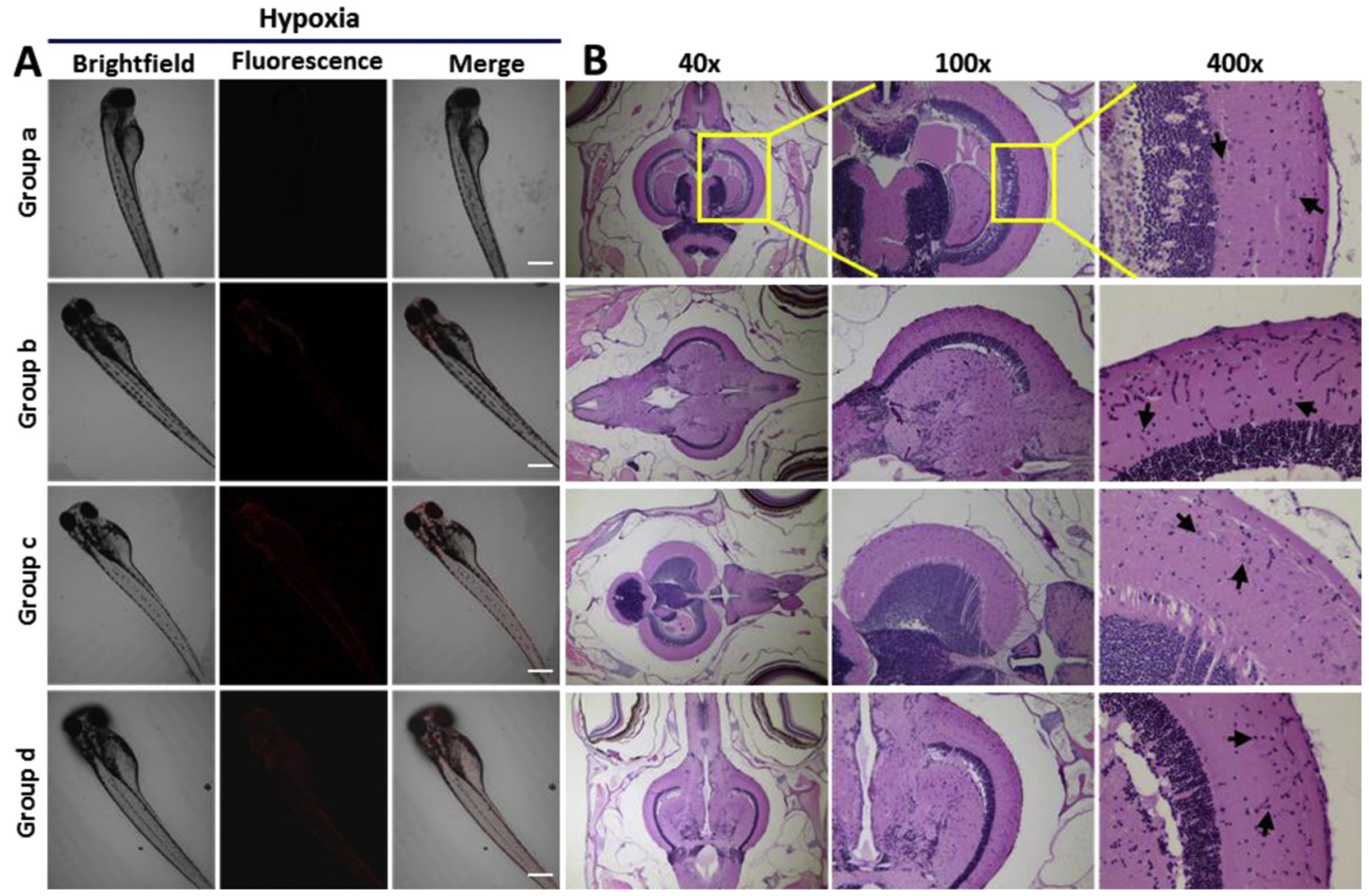

Fig. 6. In situ imaging and efficacy evaluation of endogenous $\mathrm{H}_{2} \mathrm{~S}_{\mathrm{n}}$ in zebrafish. A: Confocal fluorescence imaging of 3dpf zebrafish. Scale bar: $300 \mu \mathrm{m}$. Group a: The zebrafish were incubated with $5 \mu \mathrm{MBCy}-\mathrm{FN}$ at $28^{\circ} \mathrm{C}$ for $10 \mathrm{~min}$ and tricaine solution was added to the petri-dish at the last $5 \mathrm{~min}$ to anesthetize. Group b: The zebrafish were cultured under $8 \%$ oxygen for hypoxia $6 \mathrm{~h}$ and then imaging after anesthetization. Group c: The zebrafish were operated as group a after preincubated with $10 \mu \mathrm{M}$ HSNO solution for $2 \mathrm{~h}$. Group d: The zebrafish were pre-incubated with HSNO solution and then operated as group b. B: Representative slides of H\&E-stained adult zebrafish brain tissue lesions. The arrows indicate representative cell states.

properties for in situ visualization with noninvasiveness. The real-time imaging of $\mathrm{H}_{2} \mathrm{~S}_{\mathrm{n}}$ in mice and zebrafish can be applied to assist in evaluating the state of oxidative stress during hypoxia process. It also makes the probe BCy-FN a potential tool for exploring interaction of $\mathrm{HSNO}-\mathrm{H}_{2} \mathrm{~S}_{\mathrm{n}}$ in biosystem in the future.

\section{CRediT authorship contribution statement}

Xia Zhang: Conceptualization, Methodology, Investigation, Formal analysis, Writing - original draft. Liangwei Zhang: Project administration, Validation, Writing - review \& editing. Min Gao: Data curation, Investigation. Yunqing Wang: Writing - review \& editing. Lingxin Chen: Supervision, Resources, Funding acquisition, Writing - review \& editing.

\section{Declaration of Competing Interest}

The authors declare that they have no known competing financial interests or personal relationships that could have appeared to influence the work reported in this paper.

\section{Acknowledgements}

This work was supported by the National Nature Science Foundation of China (Grant Nos. 21976209 and 21778026), the program of Youth Innovation Promotion Association, CAS (Grant Nos. 2017256, 2019217) and Research Initiation Fund of Binzhou Medical University (Grant No. BY2019KYQD39) and Taishan Scholar Project Special Funding (Grant No. ts20190962).
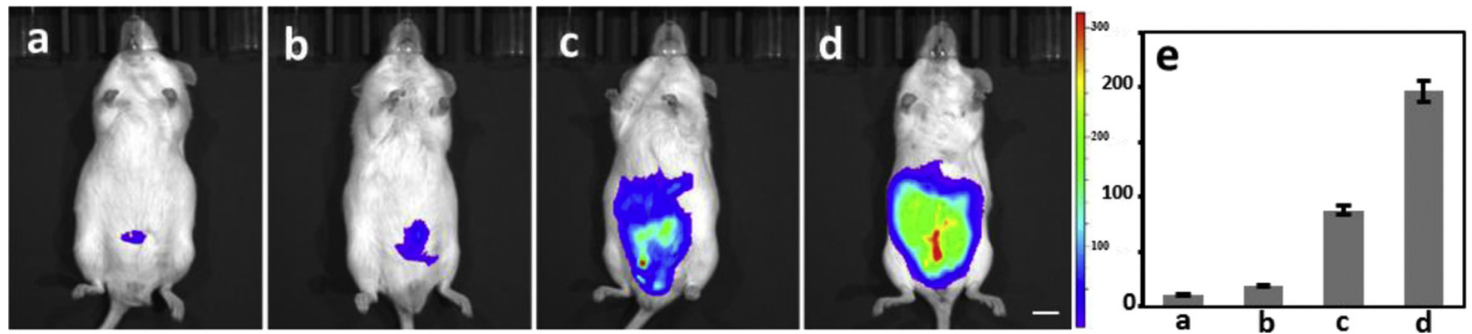

Fig. 7. In vivo imaging of HSNO-mediated $\mathrm{H}_{2} \mathrm{~S}_{\mathrm{n}}$ levels in $\mathrm{BALB} / \mathrm{c}$ mice peritoneal cavity. All the experimental mice were administered i.p. injection of $\mathrm{BCy}-\mathrm{FN}$ (50 $\mu \mathrm{M}$, $50 \mu \mathrm{L}$, in DMSO/saline, v/v 1:9) for 20 min before imaging, $\lambda_{\text {em }}=700-800 \mathrm{~nm}\left(\lambda_{\text {ex }}=635 \mathrm{~nm}\right.$ ). Scale bar: $1 \mathrm{~cm}$. (a) The mice were only injected probe. (b) The mice were i.p. injected with HSNO solution ( $500 \mu \mathrm{M}, 50 \mu \mathrm{L}$ in saline) for $30 \mathrm{~min}$. (c) Treated mice as (b) and then injected NaHS (250 $\mu \mathrm{M}, 100 \mu \mathrm{L}$ in saline) for $30 \mathrm{~min}$. (d) The mice were given an i.p. injection with $\mathrm{Na}_{2} \mathrm{~S}_{2}(50 \mu \mathrm{M}, 100 \mu \mathrm{L}$ in saline) for $30 \mathrm{~min}$. (e) Average values of total photon flux in Fig. $7 \mathrm{a}-\mathrm{d}$, the data are exhibited as mean $( \pm$ s.d. $)(n=6)$. 


\section{Appendix A. Supplementary data}

Supplementary material related to this article can be found, in the online version, at doi:https://doi.org/10.1016/j.jhazmat.2020.122673.

\section{References}

Chen, W., Rosser, E.W., Matsunaga, T., Pacheco, A., Akaike, T., Xian, M., 2015. The development of fluorescent probes for visualizing intracellular hydrogen polysulfides. Angew. Chem. Int. Ed. 54, 13961-13965. https://doi.org/10.1002/anie.201506887.

Chen, W., Pacheco, A., Takano, Y., Day, J.J., Hanaoka, K., Xian, M., 2016. A single fluorescent probe to visualize hydrogen sulfide and hydrogen polysulfides with different fluorescence signals. Angew. Chem. Int. Ed. 55, 9993-9996. https://doi.org/ 10.1002/anie.201604892.

Chen, W., Matsunaga, T., Neill, D.L., Yang, C.T., Akaike, T., Xian, M., 2019. Rational design of a dual-reactivity based fluorescent probe for visualizing intracellular HSNO. Angew. Chem. Int. Ed. 131, 16213-16216. https://doi.org/10.1002/anie. 201908950.

Cheng, D., Peng, J., Lv, Y., Su, D., Liu, D., Chen, M., Yuan, L., Zhang, X., 2019. De novo design of chemical stability near-infrared molecular probes for high-fidelity hepatotoxicity evaluation in vivo. J. Am. Chem. Soc. 141, 6352-6361. https://doi.org/10. 1021/jacs.9b01374.

Cortese-Krott, M.M., Kuhnle, G.G., Dyson, A., Fernandez, B.O., Grman, M., DuMond, J.F., Nagy, P., 2015. Key bioactive reaction products of the NO/H2S interaction are S/Nhybrid species, polysulfides, and nitroxyl. Proc. Natl. Acad. Sci. U. S. A. 112, E4651-E4660. https://doi.org/10.1073/pnas.1509277112.

Fang, Y., Chen, W., Shi, W., Li, H., Xian, M., Ma, H., 2017. A near-infrared fluorescence off-on probe for sensitive imaging of hydrogen polysulfides in living cells and mice in vivo. Chem. Commun. 53, 8759-8762. https://doi.org/10.1039/c7cc04093h.

Filipovic, M.R., Miljkovic, J.L., Nauser, T., Royzen, M., Klos, K., Shubina, T., Koppenol, W.H., Lippard, S.J., Ivanović-Burmazović, I., 2012. Chemical characterization of the smallest S-nitrosothiol, HSNO; cellular cross-talk of H2S and S-nitrosothiols. J. Am. Chem. Soc. 134, 12016-12027. https://doi.org/10.1021/ja3009693.

Filipovic, M.R., Zivanovic, J., Alvarez, B., Banerjee, R., 2017. Chemical biology of H2S signaling through persulfidation. Chem. Rev. 118, 1253-1337. https://doi.org/10. 1021/acs.chemrev.7b00205.

Fu, M., Zhang, W., Wu, L., Yang, G., Li, H., Wang, R., 2012. Hydrogen sulfide (H2S) metabolism in mitochondria and its regulatory role in energy production. Proc. Natl. Acad. Sci. U. S. A. 109, 2943-2948. https://doi.org/10.1073/pnas.1115634109.

Gao, M., Yu, F., Chen, H., Chen, L., 2015. Near-infrared fluorescent probe for imaging mitochondrial hydrogen polysulfides in living cells and in vivo. Anal. Chem. 87, 3631-3638. https://doi.org/10.1021/ac5044237.

Gao, M., Wang, R., Yu, F., Chen, L., 2018. Evaluation of sulfane sulfur bioeffects via a mitochondria-targeting selenium-containing near-infrared fluorescent probe. Biomaterials 160, 1-14. https://doi.org/10.1016/j.biomaterials.2018.01.011.

Gong, X., Yang, X.F., Zhong, Y., Chen, H., Li, Z., 2016. A flavylium-based turn-on fluorescent probe for imaging hydrogen polysulfides in living cells. RSC Adv. 6 , 88519-88525. https://doi.org/10.1039/C6RA21145C.

Gruhlke, M.C., Slusarenko, A.J., 2012. The biology of reactive sulfur species (RSS). Plant Physiol. Biochem. 59, 98-107. https://doi.org/10.1016/j.plaphy.2012.03.016.

Han, L., Shi, R., Xin, C., Ci, Q., Ge, J., Liu, J., Huang, W., 2018. Mitochondrial specific H2Sn fluorogenic probe for live cell imaging by rational utilization of a dual-functional-photocage group. ACS Sens. 3, 1622-1626. https://doi.org/10.1021/ acssensors.8b00456.

Hou, Y., Yang, X.F., Zhong, Y., Li, Z., 2016. Development of fluorescent probes for hydrogen polysulfides by using cinnamate ester as the recognition unit. Sens. Actuators B-Chem. 232, 531-537. https://doi.org/10.1016/j.snb.2016.04.008.

Huang, Y., Yu, F., Wang, J., Chen, L., 2016. Near-infrared fluorescence probe for in situ detection of superoxide anion and hydrogen polysulfides in mitochondrial oxidative stress. Anal. Chem. 88, 4122-4129. https://doi.org/10.1021/acs.analchem.6b00458.

Ida, T., Sawa, T., Ihara, H., Tsuchiya, Y., Watanabe, Y., Kumagai, Y., Yamamoto, M. 2014. Reactive cysteine persulfides and S-polythiolation regulate oxidative stress and redox signaling. Proc. Natl. Acad. Sci. U. S. A. 111, 7606-7611. https://doi.org/10. 1073/pnas.1321232111.

Islam, A.S.M., Bhowmick, R., Pal, K., Katarkar, A., Chaudhuri, K., Ali, M., 2017. A smart molecule for selective sensing of nitric oxide: conversion of NO to HSNO; relevance of biological HSNO formation. Inorg. Chem. 56, 4324-4331. https://doi.org/10.1021/ acs.inorgchem.6b02787.

Jung, H.S., Lee, J.H., Kim, K., Koo, S., Verwilst, P., Sessler, J.L., Kang, C., Kim, J.S., 2017. A mitochondria-targeted cryptocyanine-based photothermogenic photosensitizer. J. Am. Chem. Soc. 139, 9972-9978. https://doi.org/10.1021/jacs.7b04263.

Kang, J., Xu, S., Radford, M.N., Zhang, W., Kelly, S.S., Day, J.J., Xian, M., 2018. O $\rightarrow$ S relay deprotection: a general approach to controllable donors of reactive sulfur species. Angew. Chem. Int. Ed. 57, 5893-5897. https://doi.org/10.1002/anie. 201802845.

Kimura, H., 2014. Hydrogen sulfide and polysulfides as biological mediators. Molecules 19, 16146-16157. https://doi.org/10.3390/molecules191016146.

Kimura, H., 2015. Hydrogen sulfide and polysulfides as signaling molecules. Proc. Jpn. Acad. B-Phys. 91, 131-159. https://doi.org/10.2183/pjab.91.131.

Kimura, H., 2019. Signaling by hydrogen sulfide (H2S) and polysulfides (H2Sn) in the central nervous system. Neurochem. Int. 126, 118-125. https://doi.org/10.1016/j. neuint.2019.01.027.

Kimura, Y., Mikami, Y., Osumi, K., Tsugane, M., Oka, J.I., Kimura, H., 2013. Polysulfides are possible H2S-derived signaling molecules in rat brain. FASEB J. 27, 2451-2457. https://doi.org/10.1096/fj.12-226415.

Koike, S., Ogasawara, Y., Shibuya, N., Kimura, H., Ishii, K., 2013. Polysulfide exerts a protective effect against cytotoxicity caused by t-buthylhydroperoxide through Nrf2 signaling in neuroblastoma cells. FEBS Lett. 587, 3548-3555. https://doi.org/10. 1016/j.febslet.2013.09.013

Kundu, K., Knight, S.F., Willett, N., Lee, S., Taylor, W.R., Murthy, N., 2009. Hydrocyanines: a class of fluorescent sensors that can image reactive oxygen species in cell culture, tissue, and in vivo. Angew. Chem. Int. Ed. 48, 299-303. https://doi. org/10.1002/anie.200804851.

Li, P., Wang, J., Wang, X., Ding, Q., Bai, X., Zhang, Y., Su, D., Zhang, W., Zhang, W., Tang, B., 2019. In situ visualization of ozone in the brains of mice with depression phenotypes by using a new near-infrared fluorescence probe. Chem. Sci. 10, 2805-2810. https://doi.org/10.1039/c8sc04891f.

Lin, V.S., Lippert, A.R., Chang, C.J., 2013. Cell-trappable fluorescent probes for endogenous hydrogen sulfide signaling and imaging H2O2-dependent $\mathrm{H} 2 \mathrm{~S}$ production. Proc. Natl. Acad. Sci. U. S. A. 110, 7131-7135. https://doi.org/10.1073/pnas. 1302193110.

Lin, V.S., Chen, W., Xian, M., Chang, C.J., 2015. Chemical probes for molecular imaging and detection of hydrogen sulfide and reactive sulfur species in biological systems. Chem. Soc. Rev. 44, 4596-4618. https://doi.org/10.1039/C4CS00298A.

Liu, C., Chen, W., Shi, W., Peng, B., Zhao, Y., Ma, H., Xian, M., 2014. Rational design and bioimaging applications of highly selective fluorescence probes for hydrogen polysulfides. J. Am. Chem. Soc. 136, 7257-7260. https://doi.org/10.1021/ja502968x.

Liu, Y., Lee, D., Wu, D., Swamy, K.M.K., Yoon, J., 2018. A new kind of rhodamine-based fluorescence turn-on probe for monitoring ATP in mitochondria. Sens. Actuators BChem. 265, 429-434. https://doi.org/10.1016/j.snb.2018.03.081.

Ma, J., Fan, J., Li, H., Yao, Q., Xu, F., Wang, J., Peng, X., 2017. A NIR fluorescent chemodosimeter for imaging endogenous hydrogen polysulfides via the CSE enzymatic pathway. J. Mater. Chem. B 5, 2574-2579. https://doi.org/10.1039/c5cc03927d.

Miyamoto, R., Koike, S., Takano, Y., Shibuya, N., Kimura, Y., Hanaoka, K., Kimura, H., 2017. Polysulfides (H2Sn) produced from the interaction of hydrogen sulfide (H2S) and nitric oxide (NO) activate TRPA1 channels. Sci. Rep. 7, 45995. https://doi.org/ 10.1038/srep45995.

Nagy, P., Winterbourn, C.C., 2010. Rapid reaction of hydrogen sulfide with the neutrophil oxidant hypochlorous acid to generate polysulfides. Chem. Res. Toxicol. 23, 1541-1543. https://doi.org/10.1021/tx100266a.

Nava, M., Martin-Drumel, M.A., Lopez, C.A., Crabtree, K.N., Womack, C.C., Nguyen, T.L., Thorwirth, S., Cummins, C.C., Stanton, J.F., McCarthy, M.C., 2016. Spontaneous and selective formation of HSNO, a crucial intermediate linking H2S and nitroso chemistries. J. Am. Chem. Soc. 138, 11441-11444. https://doi.org/10.1021/jacs. 6b05886.

Ono, K., Akaike, T., Sawa, T., Kumagai, Y., Wink, D.A., Tantillo, D.J., Fukuto, J.M., 2014. Redox chemistry and chemical biology of H2S, hydropersulfides, and derived species: implications of their possible biological activity and utility. Free Rad. Bio. Me. 77, 82-94. https://doi.org/10.1016/j.freeradbiomed.2014.09.007.

Paulsen, C.E., Carroll, K.S., 2013. Cysteine-mediated redox signaling: chemistry, biology, and tools for discovery. Chem. Rev. 113, 4633-4679. https://doi.org/10.1021/ cr300163e.

Sedgwick, A.C., Wu, L., Han, H.H., Bull, S.D., He, X.P., James, T.D., Sessler, J.L., Tang, B.Z., Tian, H., Yoon, J., 2018. Excited-state intramolecular proton-transfer (ESIPT) based fluorescence sensors and imaging agents. Chem. Soc. Rev. 47, 8842-8880. https://doi.org/10.1039/c8cs00185e.

Shang, H., Chen, H., Tang, Y., Guo, R., Lin, W., 2016. Construction of a two-photon fluorescent turn-on probe for hydrogen persulfide and polysulfide and its bioimaging application in living mice. Sens. Actuators B-Chem. 230, 773-778. https://doi.org/ 10.1016/j.snb.2016.02.124.

Toohey, J.I., Cooper, A.J., 2014. Thiosulfoxide (sulfane) sulfur: new chemistry and new regulatory roles in biology. Molecules 19, 12789-12813. https://doi.org/10.3390/ molecules190812789.

Xu, W., Teoh, C.L., Peng, J., Su, D., Yuan, L., Chang, Y.T., 2015. A mitochondria-targeted ratiometric fluorescent probe to monitor endogenously generated sulfur dioxide derivatives in living cells. Biomaterials 56, 1-9. https://doi.org/10.1016/j.biomaterials. 2015.03.038.

Yadav, P.K., Martinov, M., Vitvitsky, V., Seravalli, J., Wedmann, R., Filipovic, M.R., Banerjee, R., 2015. Biosynthesis and reactivity of cysteine persulfides in signaling. J. Am. Chem. Soc. 138, 289-299. https://doi.org/10.1021/jacs.5b10494.

Yang, F., Gao, H., Li, S.S., An, R.B., Sun, X.Y., Kang, B., Xu, J.J., Chen, H.Y., 2018. A fluorescent $\tau$-probe: quantitative imaging of ultra-trace endogenous hydrogen polysulfide in cells and in vivo. Chem. Sci. 9, 5556-5563. https://doi.org/10.1039/ c8sc01879k.

Yu, F., Gao, M., Li, M., Chen, L., 2015. A dual response near-infrared fluorescent probe for hydrogen polysulfides and superoxide anion detection in cells and in vivo. Biomaterials 63, 93-101. https://doi.org/10.1016/j.biomaterials.2015.06.007.

Yuan, L., Wang, L., Agrawalla, B.K., Park, S.J., Zhu, H., Sivaraman, B., Peng, J.J., Xu, Q.H., Chang, Y.T., 2015. Development of targetable two-photon fluorescent probes to image hypochlorous acid in mitochondria and lysosome in live cell and inflamed mouse model. J. Am. Chem. Soc. 137, 5930-5938. https://doi.org/10.1021/jacs. 5 b00042.

Zeng, L., Chen, S., Xia, T., Hu, W., Li, C., Liu, Z., 2015. Two-photon fluorescent probe for detection of exogenous and endogenous hydrogen persulfide and polysulfide in living organisms. Anal. Chem. 87, 3004-3010. https://doi.org/10.1021/acs.analchem. 5b00172.

Zhang, J., Zhu, X.Y., Hu, X.X., Liu, H.W., Li, J., Feng, L.L., Yin, X., Zhang, X.B., Tan, W., 2016. Ratiometric two-photon fluorescent probe for in vivo hydrogen polysulfides detection and imaging during lipopolysaccharide-induced acute organs injury. Anal. Chem. 88, 11892-11899. https://doi.org/10.1021/acs.analchem.6b03702.

Zhang, X., Huang, Y., Han, X., Wang, Y., Zhang, L., Chen, L., 2019. Evaluating the protective effects of mitochondrial glutathione on cerebral ischemia/reperfusion injury via near-infrared fluorescence imaging. Anal. Chem. 91, 14728-14736. https://doi. org/10.1021/acs.analchem.9b04082.

Zhu, X.Y., Liu, S.J., Liu, Y.J., Wang, S., Ni, X., 2010. Glucocorticoids suppress cystathionine gamma-lyase expression and $\mathrm{H} 2 \mathrm{~S}$ production in lipopolysaccharidetreated macrophages. Cell. Mol. Life Sci. 67, 1119-1132. https://doi.org/10.1007/ s00018-009-0250-9. 